\title{
Hybrid Energy System Cost Analysis: San Nicolas Island, California
}

Timothy L. Olsen

Timothy L. Olsen Consulting

Ed McKenna

National Renewable Energy Laboratory

NREL technical monitor: Ed McKenna

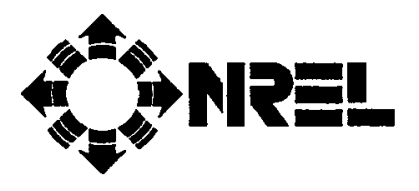

National Renewable Energy Laboratory 1617 Cole Boulevard

Golden, Colorado 80401-3393

A national laboratory of the U.S. Department of Energy Managed by Midwest Research Institute for the U.S. Department of Energy under contract No. DE-AC36-83CH10093

Prepared under Subcontract No. CAK-6-15387-01

July 1996 


\begin{abstract}
NOTICE
This report was prepared as an account of work sponsored by an agency of the United States government. Neither the United States government nor any agency thereof, nor any of their employees, makes any warranty, express or implied, or assumes any legal liability or responsibility for the accuracy, completeness, or usefulness of any information, apparatus, product, or process disclosed, or represents that its use would not infringe privately owned rights. Reference herein to any specific commercial product, process, or service by trade name, trademark, manufacturer, or otherwise does not necessarily constitute or imply its endorsement, recommendation, or favoring by the United States govemment or any agency thereof. The views and opinions of authors expressed herein do not necessarily state or reflect those of the United States government or any agency thereof.
\end{abstract}

Available to DOE and DOE contractors from:

Office of Scientific and Technical Information (OSTI)

P.O. Box 62

Oak Ridge, TN 37831

Prices available by calling (423) $576-8401$

Available to the public from:

National Technical Information Service (NTIS)

U.S. Department of Commerce

5285 Port Royal Road

Springfield, VA 22161

(703) $487-4650$ 


\section{CONTENTS}

Foreword ... Page

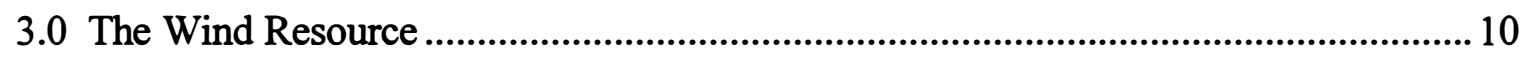

3.1 Historical Wind Data................................................................................. 10

3.2 Current Wind Data .................................................................................... 11

4.0 Proposed Energy System and Analysis ................................................................ 14

4.1 Hybrid System ............................................................................................. 14

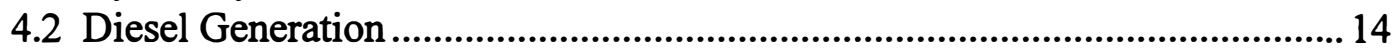

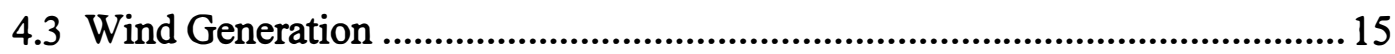

4.4 Load Profile ........................................................................................................ 16

4.5 Wind Profile ............................................................................................. 17

4.6 Hybrid System Spreadsheet Model ................................................................... 17

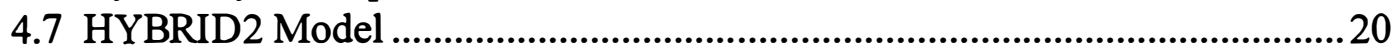

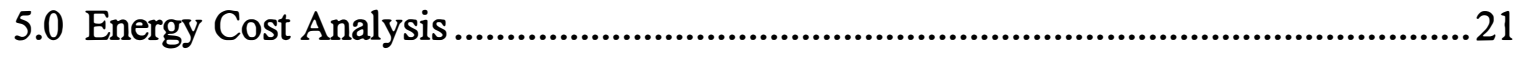

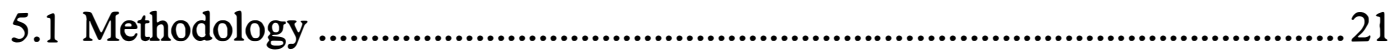

5.2 Existing System Costs................................................................................... 21

5.3 Hybrid System Costs .................................................................................22

5.4 Hybrid System Spreadsheet Model Savings .....................................................23

5.5 Wind Speed Sensitivity .....................................................................................2

5.6 HYBRID2 Model Savings.............................................................................26

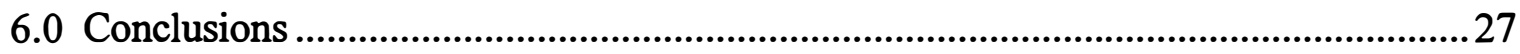

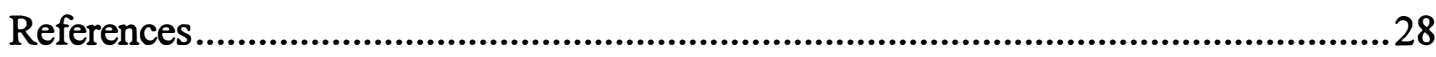

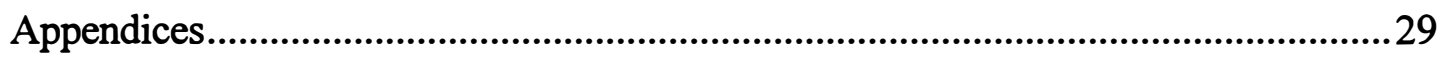




\section{LIST OF TABLES}

$\underline{\text { Page }}$

1. Power Rating and Fuel Consumption................................................................ 4

2. SNI Available System Demand Statistics .............................................................

3. Summary of Current SNI Meteorological Data................................................... 12

4. 1995 Hybrid Systems vs. Baseline: Spreadsheet Model Results ........................... 19

5. Diesel Operations and Maintenance Costs ........................................................22

6. Balance of Station for Four $225 \mathrm{~kW}$ Wind Turbines ............................................23

7. Economic Sensitivity to Wind Speed Variations ..................................................25 


\section{LIST OF FIGURES}

$\underline{\text { Page }}$

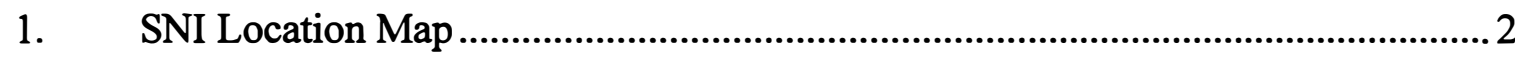

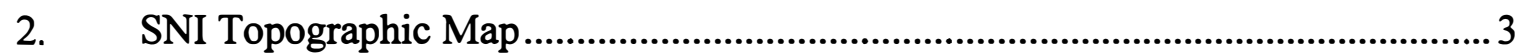

3. SNI Naval Facilities and Potential Wind Farm Site ............................................

4. SNI Load Frequency Distribution ....................................................................... 8

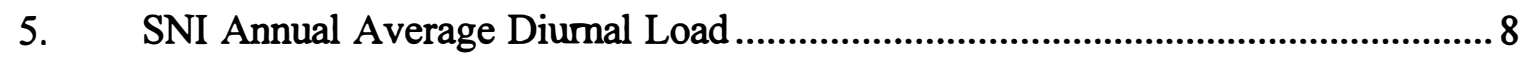

6. SNI Annual Energy Production Record ...........................................................

7. SNI Annual Fuel Consumption Record.............................................................

8. SNI Energy Production vs Fuel Consumption ................................................... 10

9. SNI Historical Wind Speeds............................................................................ 11

10. SNI Wind Speed Frequency Distribution......................................................... 12

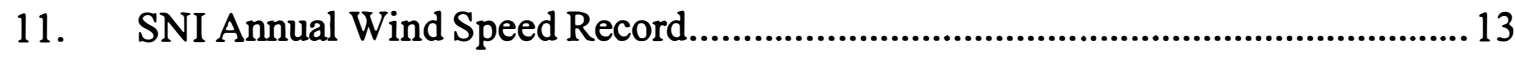

12. SNI Annual Average Diumal Wind Speed ........................................................ 13

13. Power Curve, $225 \mathrm{~kW}$ Wind Turbine................................................................ 16

14. SNI Diumal Load and Wind Speed Overlay ...................................................... 17

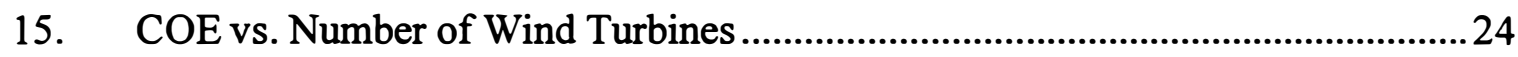

16. Payback Period vs. Number of Wind Turbines .....................................................24

17. Internal Rate of Return vs. Number of Wind Turbines ..........................................25 


\section{FOREWORD}

This report was prepared as an account of work for others funding contract, sponsored by the Department of Defense (DoD) Strategic Environmental Research and Development Program (SERDP) under Department of Energy (DOE) Contract \# DE-AC02-83CH10093.

The objective of this joint DOE and National Renewable Energy Laboratory (NREL) SERDP project is to determine whether wind turbines can reduce costs by providing power to US military facilities in high wind areas. In support of this objective, one year of data on the wind resources of San Nicolas Island was collected and presented in the report NREL/TP 44-20231 "Wind Resource Assessment: San Nicolas Island, California" [1]. The wind resource data was used as input to economic and feasibility studies for a wind-diesel hybrid installation for San Nicolas Island (SNI). The results of this hybrid system study are presented here.

Timothy L. Olsen, an engineering consultant, was contracted by NREL to provide data reduction analysis, research historical wind resource data, perform wind-diesel hybrid analysis, and generate this report. 


\section{ACKNOWLEDGMENTS}

The authors wish to acknowledge major contributions to the success of this project by Bob Keller and Bill Gage of Mountain Valley Energy, who helped to install, commission, and operate the meteorological test equipment. Sherwin West also helped process large quantities of wind resource data. Neil Kelley of NREL shared his meteorological advice and guidance in presentation and interpretation of the wind resource data. Dennis Elliott and Mark Schwartz of NREL helped us track down historical site data. Ron Vincent of NFESC, the SNI project manager, advised on all aspects of SNI facilities, costs, and operations, and Carrie Eller, the Head of Utilities Management at Point Mugu, helped to ferret out detailed cost breakdowns for the whole SNI energy system. Lieutenant Commander Egeln, USN Officer in Charge for San Nicolas Island and USN Point Mugu Energy and Public Works Center (PWC) office made the site available for study and arranged travel to and from SNI. Scott Miller of NFESC assisted with instrumentation, and the rest of the SNI Navy support staff assisted with this project in countless ways. Curt Jonas executed the details of developing the spreadsheet-based hybrid system and economics models. Kristin Olsen of KO Consulting developed and refined the numerous graphs in the report. $\mathrm{Al}$ Miller of Problem Solvers International provided substantial advice on understanding hybrid system modeling and interpreting the pertinent data. Ian Baring-Gould and Vincent van Dijk of NREL provided training in the use of the HYBRID2 computer program and guidance in developing, troubleshooting, and interpreting the hybrid system models. Each of these people deserves special thanks for their role in bringing this project together. 


\section{EXECUTIVE SUMMARY}

San Nicolas Island has an excellent wind resource, with an annual average wind speed of $7.2 \mathrm{~m} / \mathrm{s}$ (14.0 knots) as measured by the National Renewable Energy Laboratory (NREL) at $30.5 \mathrm{~m}$ (100 ft) at Facility No. 186 in the August 1994 - July 1995 data collection period. Recognizing this, a hybrid energy system was modeled to examine the merits of supplementing the existing diesel generators with a modest portion of wind energy generation. Using conservative assumptions (unfavorable to wind energy) at every step in the spreadsheet model, the hybrid system displayed favorable operation and economics. The levelized cost of energy (COE) for the hybrid case using four $225 \mathrm{~kW}$ wind turbines is $\$ 0.338 / \mathrm{kWh}$ vs. $\$ 0.358 / \mathrm{kWh}$ for the baseline case. This would create a COE savings of $5.6 \%$. The payback period is 6.97 years, the internal rate of return $13.1 \%$. The two-turbine case had a COE of $\$ 0.342 / \mathrm{kWh}$, saving $4.5 \%$, with a payback period of 5.29 years, and an internal rate of return of $18.2 \%$. The COE for this case is relatively insensitive to annual average wind speed, varying $1 \%$ for a $10 \%$ change in wind speed. But the payback period is quite sensitive to wind speed, varying $11 \%$ to $17 \%$ for a $10 \%$ change in wind speed.

This work presented a preliminary study of a hybrid system using between 1 and 4 wind turbines. For the conditions examined here, it appears wind energy will be cost effective in this application. We believe these conditions are realistic. But certainly many alternatives to these cases merit consideration. For instance, it appears that the wind penetration could be increased, thus producing further, yet diminishing, savings. If greater redundancy is required, larger numbers of smaller turbines could be used. Smaller wind turbines would have similar relative performance as those machines examined here, with slightly higher per-energy costs and a somewhat limited selection.

Moreover, excess electrical energy should not be curtailed or wasted on dump loads; rather, it should be used for beneficial purposes, provided those purposes make economic sense. Within the San Nicolas Island electrical grid, such benefits may be realized by using excess wind energy for deferrable loads such as the SNI reverse osmosis water system, water heating, or space heating.

Different economic assumptions, such as higher and lower inflation, do not appear to have much impact on the results, but they also should be examined. Because cost and savings components are well distributed, there does not appear to be a dominant factor affecting the economic results. Factors that could affect the results include the actual capital and installation costs of the wind equipment, diesel fuel costs, and diesel system operations and maintenance and overhaul costs.

As a preliminary review, this study used 1 hour average wind and load data for the hybrid system modeling, which can give only a general sense of economic tradeoffs. Before making any final decisions about a wind-diesel hybrid electrical generation system, a more detailed analysis is recommended. Dynamic load management should be addressed using load and wind data at shorter intervals ( 2 minute or less) to grasp a more realistic picture of load and wind dynamics. 2 minute wind resource data is available from the NREL 1994-1995 measurements. However, 2 minute load data would need to be obtained. 


\subsection{INTRODUCTION}

This report analyzes the local wind resource and evaluates the costs and benefits of supplementing the current diesel-powered energy system on San Nicolas Island, California (SNI), with wind turbines. In Section 2.0 the SNI site, naval operations, and current energy system are described, as are the data collection and analysis procedures. Section 3.0 summarizes the wind resource data and analyses that were presented in NREL/TP 442-20231 [1]. Sections 4.0 and 5.0 present the conceptual design and cost analysis of a hybrid wind and diesel energy system on SNI, with conclusions following in Section 6. Appendix A presents summary pages of the hybrid system spreadsheet model, and Appendix B contains input and output files for the HYBRID2 program.

\subsection{BACKGROUND}

\subsection{San Nicolas Island}

SNI is the site of the US Navy Range Instrumentation Test Site, which relies on an isolated dieselpowered grid for its energy needs. As shown in Figure 1, the island is located in the Pacific Ocean $137 \mathrm{~km}(85 \mathrm{miles})$ southwest of Los Angeles, California, and $105 \mathrm{~km}$ (65 miles) south of the Naval Air Weapons Station (NAWS), Point Mugu, California. SNI is situated on the continental shelf at latitude $\mathrm{N} 33^{\circ} 14^{\prime}$ and longitude $\mathrm{W} 119^{\circ} 27^{\prime}$. It is approximately $15 \mathrm{~km}$ (9 miles) long and $5.8 \mathrm{~km}$ (3.6 miles) wide and encompasses an area of $54.10 \mathrm{sq} \mathrm{km} \mathrm{(13,370} \mathrm{acres)} \mathrm{of} \mathrm{land} \mathrm{owned} \mathrm{by} \mathrm{the}$ Navy [2].

The island, generally treeless, is relatively flat on top and drops sharply off on the south side with a more gradual slope to the ocean on the north side. The island's shoreline is formed by cliffs. The interior terrain is a rolling mesa, extensively eroded with little vegetation, mostly coarse grasses and few large shrubs. Its highest point is $276 \mathrm{~m}$ (907 ft) high. The western end contains large shifting sand dunes, and the eastern end has a large sand spit extending eastward. Cliffs on the southern side of the island rise sharply from the sea to $213 \mathrm{~m} \mathrm{(700} \mathrm{ft)} \mathrm{within} \mathrm{a} \mathrm{mile} \mathrm{of} \mathrm{shore;} \mathrm{cliffs}$ on the northern side of the island rise to the mesa at $91-122 \mathrm{~m}(300-400 \mathrm{ft})$ above sea level [2]. A topographic map of the island is shown in Figure 2.

The average mean monthly temperature on $\mathrm{SNI}$ is $15^{\circ} \mathrm{C}\left(59^{\circ} \mathrm{F}\right)$. In general, daily maximum temperatures vary from 16 to $21^{\circ} \mathrm{C}\left(60\right.$ to $\left.70^{\circ} \mathrm{F}\right)$, and daily minimum temperatures vary from 9 to $14^{\circ} \mathrm{C}\left(48\right.$ to $\left.58^{\circ} \mathrm{F}\right)$. The coolest month is usually January, and the warmest month is usually September. No freezing temperatures have been recorded on SNI, but temperatures above $38^{\circ} \mathrm{C}$ $\left(100^{\circ} \mathrm{F}\right)$ have been recorded several times. Precipitation averages only $20.1 \mathrm{~cm}(7.91 \mathrm{in}$.$) per year,$ and $86 \%$ of the rain falls from November through February. The relative humidity ranges from $57 \%$ to $100 \%$. 
Winds on SNI are prevailingly northwest and are strong most of the year. The average wind speed is $7.2 \mathrm{~m} / \mathrm{s}$ (14 knots) and seasonal variation is small. The windiest months, March through July, have wind speeds averaging $8.2 \mathrm{~m} / \mathrm{s}$ (16 knots). The least windy months, August through February, have wind speeds averaging $6.2 \mathrm{~m} / \mathrm{s}$ (12 knots).

Much of SNI is used as the Navy Range Instrumentation Test Site. The island is equipped with facilities supporting metric radar, telemetry, Extended Area Test System, optics, communications, microwave, missile launching, drone launching, surveillance radar, and target control. The main support facilities include a runway, an air terminal, housing, a power plant, a fuel farm, a reverse osmosis water system, and a public works and transportation building [2].

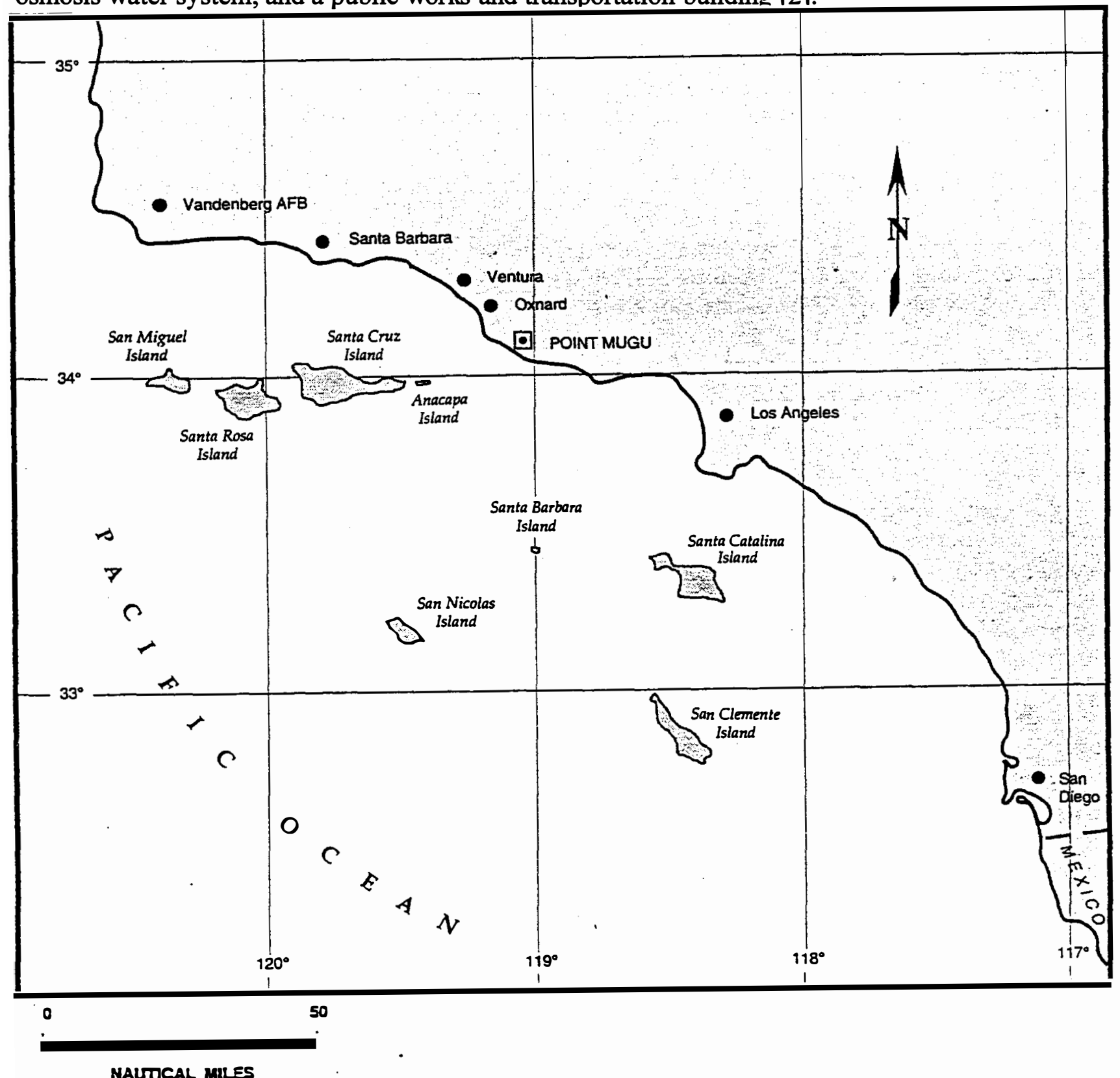

Figure 1: SNI Location Map

Source: San Nicolas Island Site Manual 
Figure 2: SNI Topographical Map

Source: San Nicolas Island Site Manual

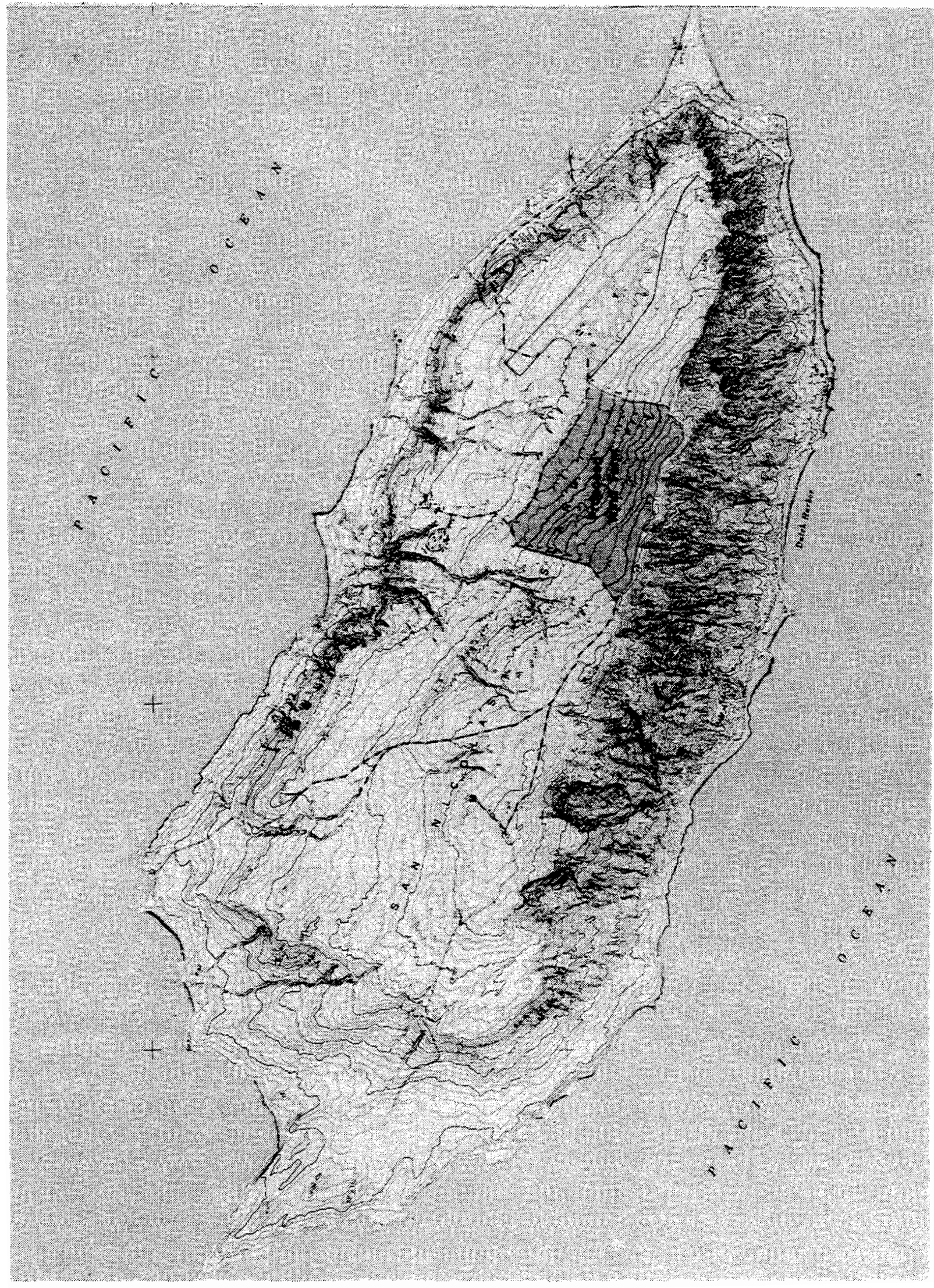




\subsection{Wind Energy Site Description}

The proposed wind energy site is located east-southeast of the center of the island, west of the airport, and along the island's crest, as shown in Figure 3. About $1.7 \mathrm{sq} \mathrm{km} \mathrm{(0.7} \mathrm{sq} \mathrm{mi)} \mathrm{in} \mathrm{area,} \mathrm{the}$ site is the west portion of the quadrant bounded by Harrington Road, Owens Road and Monroe Drive. The highest elevation, $249 \mathrm{~m}(818 \mathrm{ft})$, occurs along Harrington Road toward Owens Road, from which the terrain slopes down to the north and northeast to $168 \mathrm{~m}(550 \mathrm{ft})$ near Monroe Drive.

There are no trees or other wind obstructions on the site, just light vegetation including grasses and cacti. Several low water tanks and buildings, including the Power Plant Island Utilities, are located upwind. The nearness of the power plant minimizes power line distances to the wind energy site.

Parts of the site are very eroded and would require some fill and stabilization. This site has energetic winds throughout the year. Although more optimal wind site locations may exist on the island, this particular site was selected because it is the only site that does not interfere with radar, communications, or other naval operations, and does not pose environmental or cultural constraints.

\subsection{Existing Energy System}

Diesel Generator Sets: Electrical power at SNI is presently supplied by five Navy-owned, 3phase, $4160 \mathrm{~V}$, diesel driven electric generators that are operated by the Public Works Department located at Point Mugu. The diesel plant on the island was rebuilt in 1986 as building N114 on Owens Road. Operating data for 1995 shows an average diesel fuel consumption rate of 3.382 $\mathrm{kWh} /$ liter $(12.802 \mathrm{kWh} / \mathrm{gal})$. Online diesel capacity typically exceeds average demand by some margin to ensure enough capacity to cover excursions and to avoid switching between diesels too often. More frequent switching causes the diesels to run below their ratings most of the time, causing a lower energy conversion efficiency. Lacking any better information on fuel consumption rates, we have assumed a no-load rate equal to $25 \%$ of the full-load rate. Then, adjustment of the baseline model for the average rate of $3.382 \mathrm{kWh} /$ liter $(12.802 \mathrm{kWh} / \mathrm{gal})$ requires a full-load fuel consumption rate of $3.840 \mathrm{kWh} /$ liter $(14.534 \mathrm{kWh} / \mathrm{gal})$. The resulting fuel rate estimates are shown in Table 1.

Table 1: Power Rating and Fuel Consumption

\begin{tabular}{lccccc} 
& \multicolumn{2}{c}{ Power Rating, $\mathrm{kW}$} & & \multicolumn{2}{c}{ Fuel Consumption, 1/hr (gal/hr) } \\
\cline { 2 - 5 } \cline { 5 - 6 } Manufacturer \& Model & Manuf. & Navy & & No Load & Full Load \\
\hline 1. CAT 3516 $(1800 \mathrm{rpm})$ & 825 & 750 & & $48.8(12.9)$ & $195.3(51.6)$ \\
2. EMD 8-645-E1 $(720 \mathrm{rpm})$ & 500 & 500 & $32.6(8.6)$ & $130.2(34.4)$ \\
3. EMD 8-645-E1 $(720 \mathrm{rpm})$ & 500 & 500 & $32.6(8.6)$ & $130.2(34.4)$ \\
4. CAT model N/A $(1800 \mathrm{rpm})$ & 830 & 750 & $48.8(12.9)$ & $195.3(51.6)$ \\
5. EMD 16-645-E1 $(720 \mathrm{rpm})$ & 1,000 & 1,000 & $65.1(17.2)$ & $260.4(68.8)$
\end{tabular}




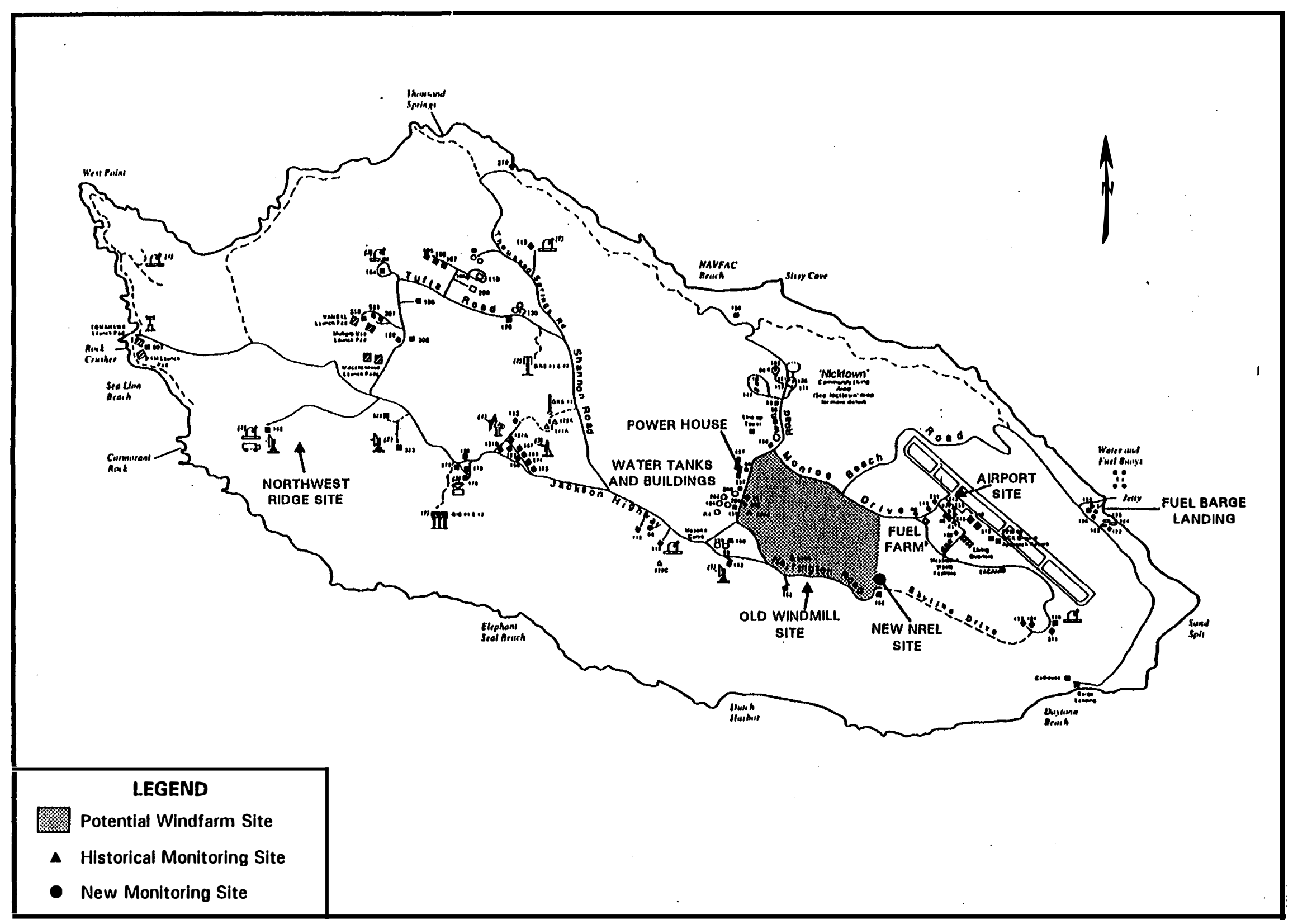

Figure 3. San Nicolas Island Naval Facilities and potential windfarm area Source: San Nicholas Island Site Manual. 
Fuel Supply System: JP-5 fuel is stored in a 37,850 liter (10,000 gallon) above-ground tank located to the south of Building N114. Fuel flows by gravity from this tank to pumps that fill the day tanks located just outside Building N114. From the day tanks, fuel flows by gravity to each operating engine's driven fuel pump. There is a plan to replace the outdoor day tanks with tanks located inside the building. The 37,850 liter (10,000 gallon) fuel tank is cleaned and refilled via trucks every 6 weeks.

An 11,355 liter (3,000 gal) lubrication oil tank is located within a double containment wall; adjacent to Building N114. An 18,925 liter (5,000 gal) truck trailer is parked adjacent to the lubrication oil tank. A quick-disconnect hose from the truck is connected to the pipe serving the permanently installed lubrication oil tank. A pump, mounted next to the lubrication oil tank, allows the transfer of oil to the engines as needed.

The plant is also provided with a waste-oil collection system. This system consists of two 11,355 liter (3,000 gal) holding tanks, two 1,893 liter (500 gal) sump tanks, and two sump pumps. The tanks and pumps are located immediately outside the power plant and are equipped with secondary containment interconnecting piping [2].

Balance of Plant: The plant is operated 24 hours per day. Operators observe equipment operation, make hourly log entries, and start and stop the generators as required. The control room has been recently upgraded and is enclosed by sound-reducing insulation and double doors leading to the engine room.

The station auxiliary equipment includes one $150 \mathrm{kVA}$, three-phase, 4160-120/208 V station service transformer, a 120/208 V distribution panel board, a $125 \mathrm{~V} \mathrm{DC}$ station battery, and two 225 $\mathrm{kVA}$, three-phase, grounded-wye-delta-connected grounding transformers, one for each bus in the switchgear to provide a neutral for single-phase, $2400 \mathrm{~V}$ loads.

The power plant switchgear, installed in 1990, has two buses with a vacuum circuit breaker tie. The circuit breaker tie will trip automatically in the event of a fault on either bus.

In addition to the $4160 \mathrm{~V}$ generators, local emergency generators provide back-up power for critical loads. The power is generated at utilization voltage $(120 / 208 \mathrm{~V}$ or $480 \mathrm{~V})$ and is applied to the load through manual or automatic transfer switches.

Distribution: Electricity is distributed throughout the island by three $12.4-\mathrm{kVA}, 4160 \mathrm{~V}$ feeders. Feeder \#1 serves most of the western half of the island; feeder \#2 serves the north-central area of the island, including personnel living facilities, administration and recreational facilities, and the public works buildings; feeder \#3 serves the air terminal and associated hangars and maintenance facilities, and two loads in the western part of the island.

The western portion of the distribution (feeder \#1 and part of feeder \#3) is completely underground [2]. Feeders \#2 and \#3 use mostly overhead lines, consisting of wood poles supporting bare copper conductors. 


\subsection{Energy Demand}

Energy production information is sparse, but some statistics follow in Table 2. The current (1995) average hourly electrical demand at SNI is $771 \mathrm{~kW}$; the hourly average peak is estimated to be $1230 \mathrm{~kW}$. The SNI grid supplies about $6.8 \mathrm{GWh}$ annually, up from $5.5 \mathrm{GWh}$ in past years.

Table 2: SNI Available System Demand Statistics

\begin{tabular}{|c|c|c|c|c|}
\hline Year & 1987 & 1989-1990 & 1993 & 1995 \\
\hline Peak demand & 950 & 1030 & 1050 & \\
\hline Low demand & & 300 & & \\
\hline Average demand $\quad(\mathrm{kW})$ & 628 & 644 & 627 & 771 \\
\hline Annual energy production ( $\mathrm{kWh}$ ) & $5,500,000$ & $5,643,600$ & $5,488,714$ & $6,753,000$ \\
\hline Annual fuel consumption & $1,498,860$ & $1,862,648$ & $1,768,587$ & $1,996,584$ \\
\hline Annual fuel consumption & 396,000 & 492,113 & 467,262 & 527,499 \\
\hline Energy / Fuel ratio $\quad(\mathrm{kWh} / \mathrm{l})$ & 3.67 & 3.04 & 3.09 & 3.38 \\
\hline Energy / Fuel ratio & 13.9 & 11.5 & 11.7 & 12.8 \\
\hline Source & $\begin{array}{r}\text { TM No. } \\
74-88-06 \\
{[3]}\end{array}$ & $\begin{array}{r}\text { Graphical } \\
\text { Data Set }\end{array}$ & $\begin{array}{c}\text { Power Plant } \\
\text { Process Data } \\
\text { Table, \& [4] }\end{array}$ & $\begin{array}{r}\text { Carrie Eller } \\
\text { FAX }\end{array}$ \\
\hline
\end{tabular}

One full year of graphical load data was digitized for input to the hybrid system model. It consists of hourly power readings from 1 October 1989 through 30 September 1990. These readings were taken from copies of the SNI power plant written log sheets and hand entered on a computer spreadsheet. All load data graphs presented in this report use the original 1989-90 data, but for hybrid system modeling these load values will be inflated $19.66 \%$ to match 1995 demand.

The load frequency distribution follows in Figure 4 with a bimodal shape, centered around 580 $\mathrm{kW}$ and $780 \mathrm{~kW}$. Annual diurnal loads are shown in Figure 5. These figures are based on the original 1989/90 loads data. Included with the data set are daily energy production and monthly fuel consumption. Annual records of monthly energy production and fuel consumption are shown in Figures 6 and 7. The plot of these two quantities in Figure 8 shows poorer correlation than expected. We don't know whether the anomalous data points result from problematic Navy record keeping, significant differences or fluctuations in diesel fuel rates, or changes in operating procedures. 


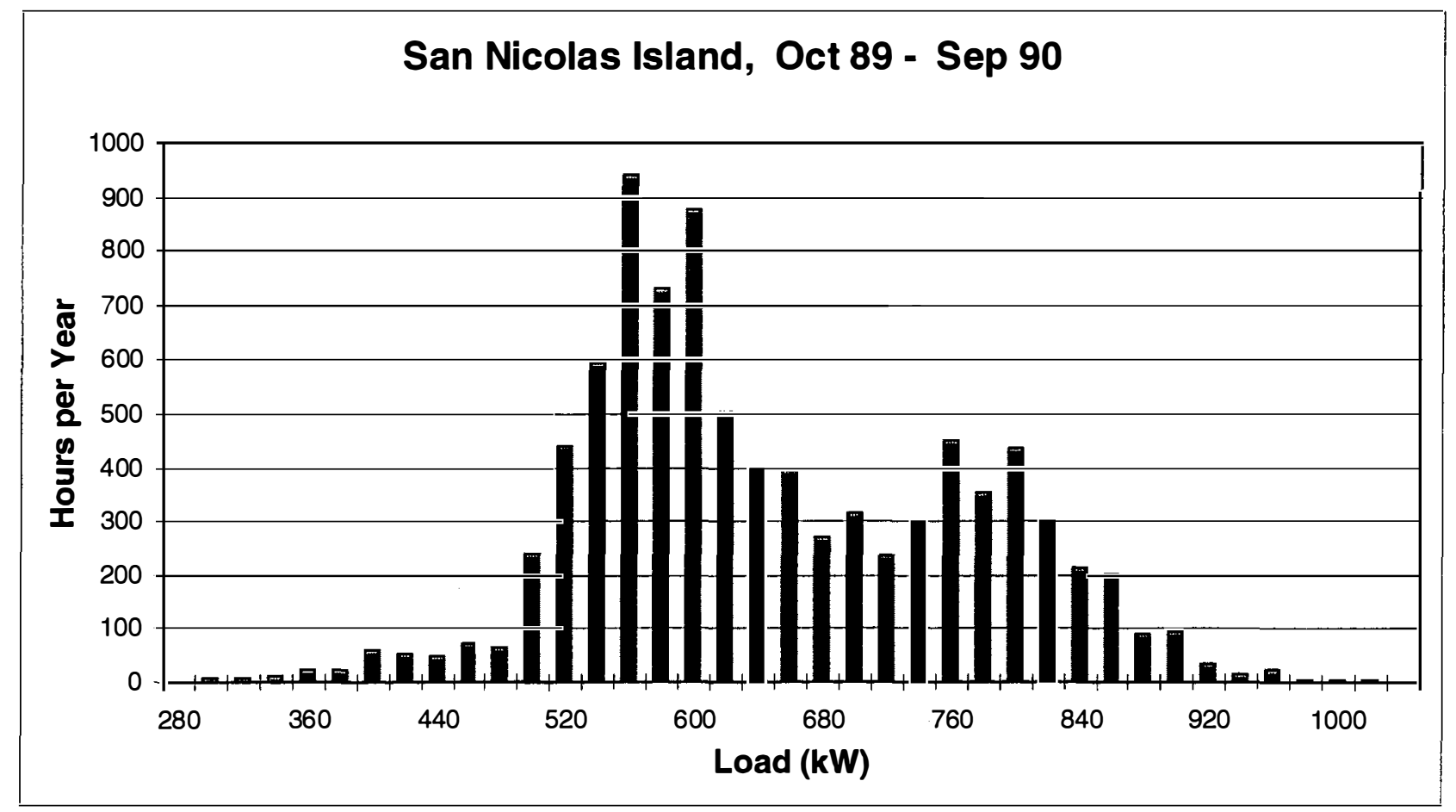

Figure 4: SNI Load Frequency Distribution

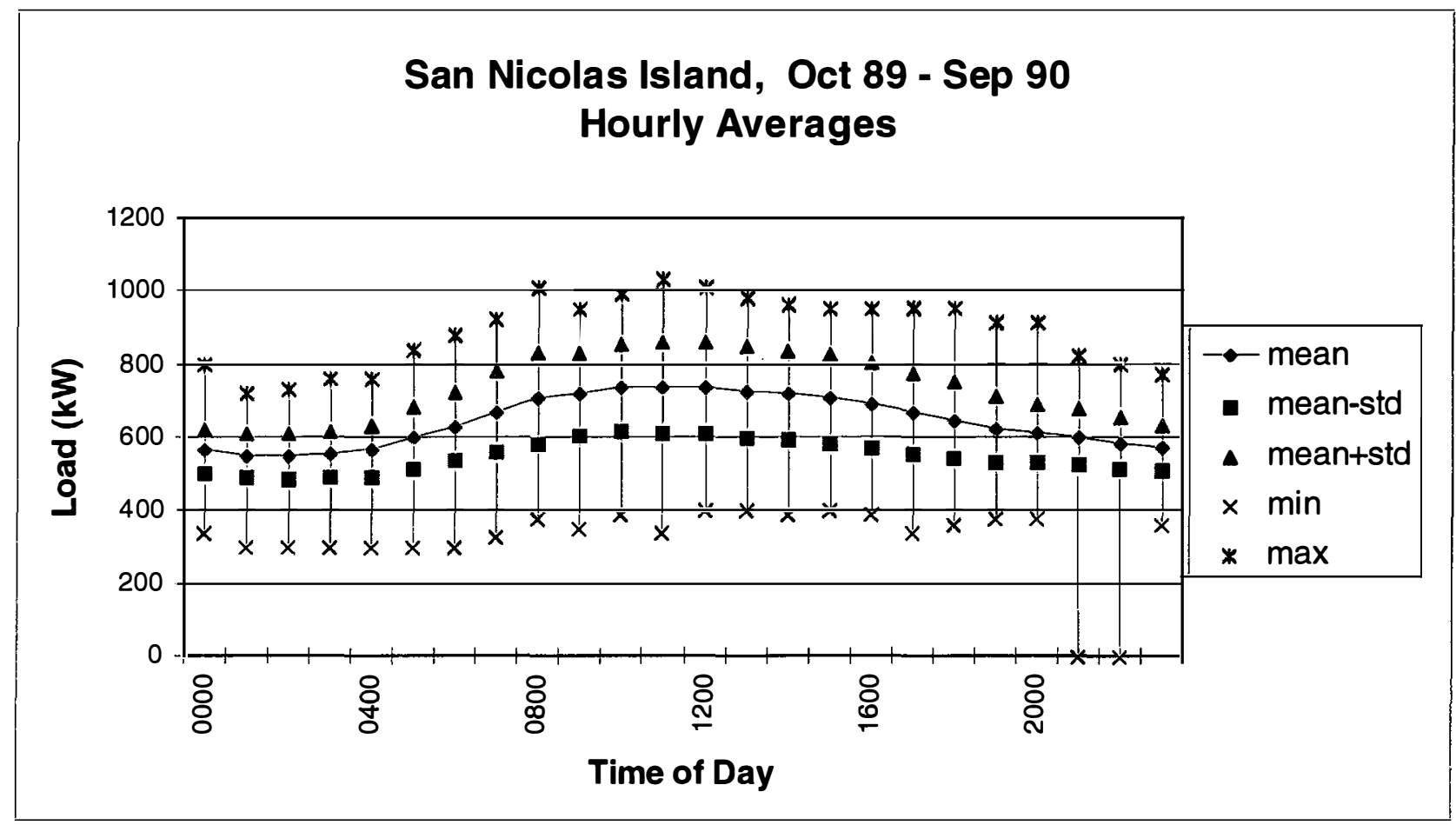

Figure 5: SNI Annual Average Diurnal Load 


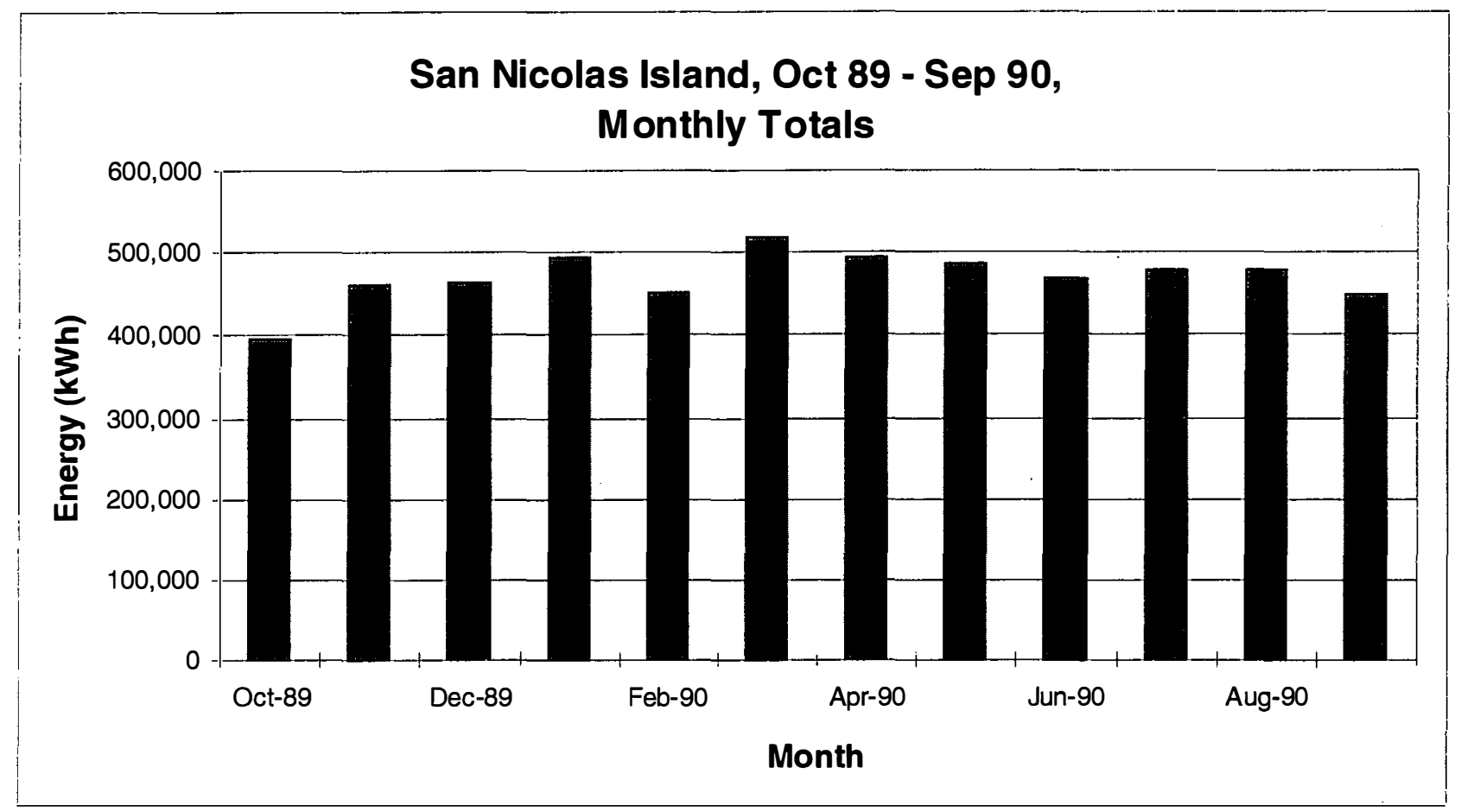

Figure 6: SNI Annual Energy Production Record

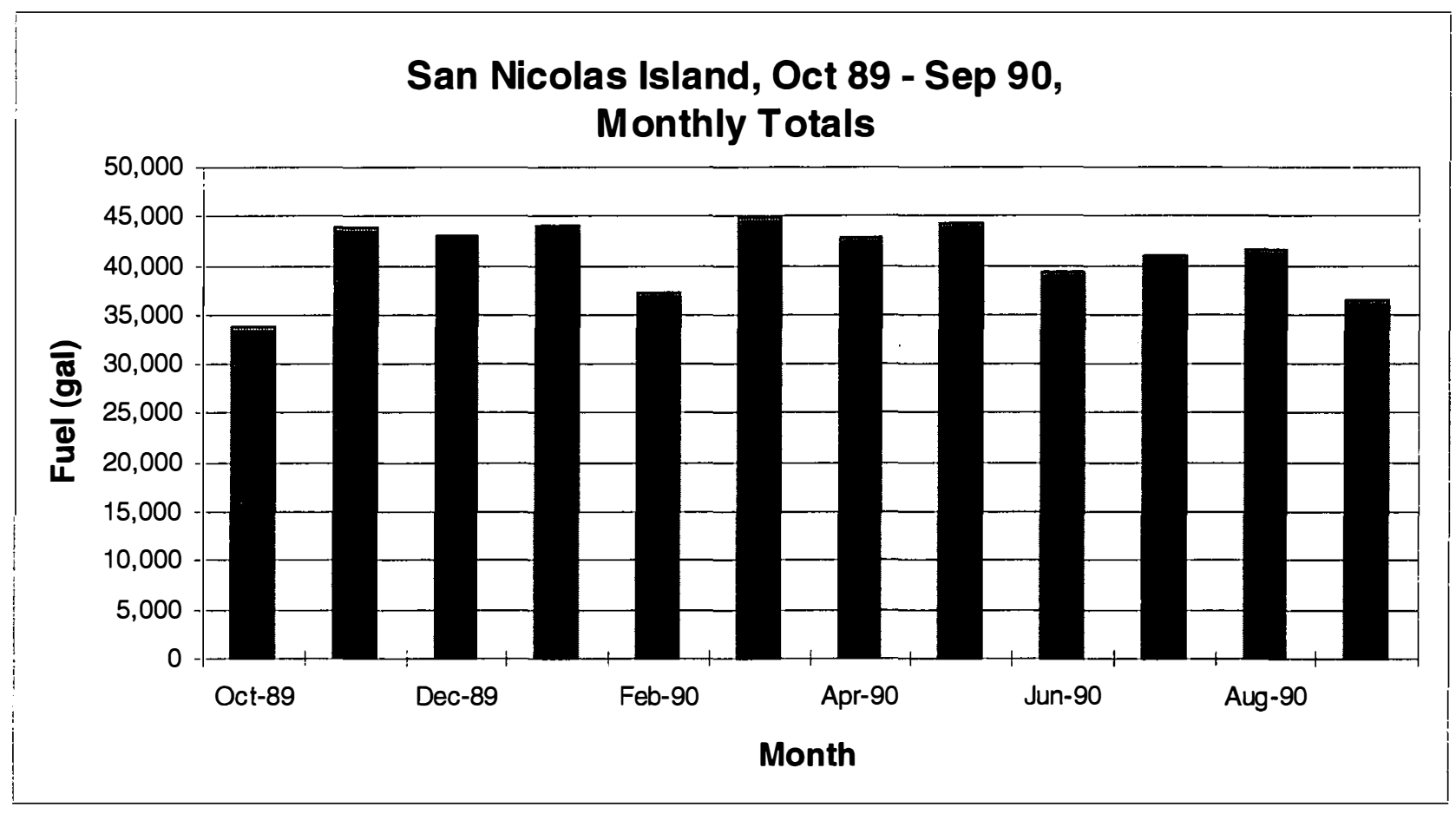

Figure 7: SNI Annual Fuel Consumption Record 


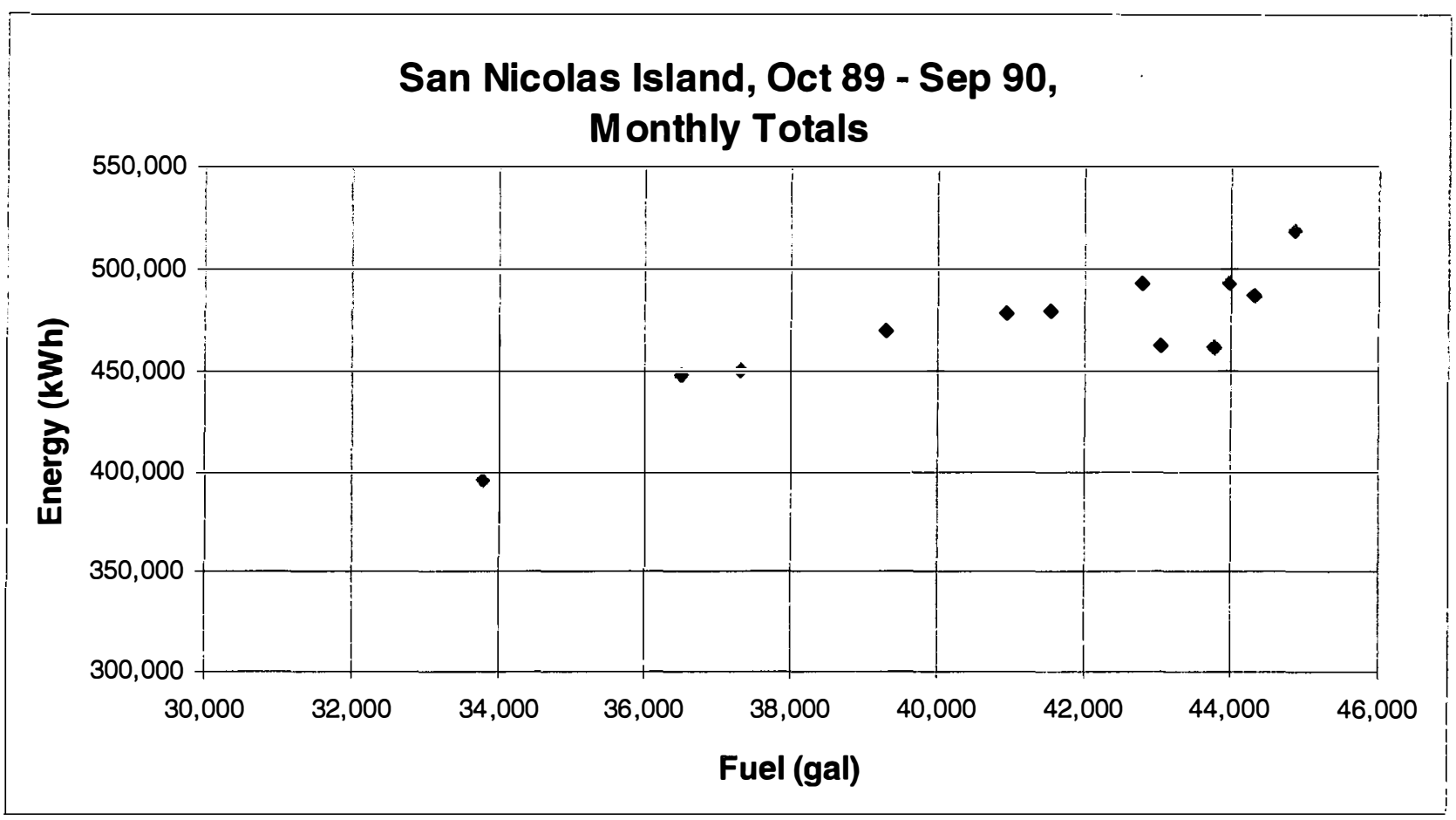

Figure 8: SNI Energy Production vs Fuel Consumption

\subsection{THE WIND RESOURCE}

In July 1994, the National Renewable Energy Laboratory (NREL) entered into a cooperative agreement with the Naval Facilities Engineering Service Center (NFESC) to collect one full year of high quality wind energy resource data at SNI Facility 186 at $30.5 \mathrm{~m}$ (100 ft) height. We examined this data in detail, and reviewed historical summary data to describe long-term behavior. Details of the data collection and analysis can be found in McKenna [1].

\subsection{Historical Wind Data}

This section begins with a review of 32 years of wind speed data (1947-1978) at SNI station number 93116, compiled by Pacific Northwest Laboratories and managed by the National Climatic Data Center [5]. Historical annual average wind speeds follow in Figure 9 and details of the analysis are presented in McKenna [1].

The average 32 year wind speed at SNI adjusted to the $30.5 \mathrm{~m}$ height is $6.1 \mathrm{~m} / \mathrm{s}$ ( $11.8 \mathrm{knots})$ based on annual averages of hourly data, and the average of the annual standard deviations is $3.8 \mathrm{~m} / \mathrm{s}$ ( 7.4 knots). The standard deviation of the annual averages is $0.6 \mathrm{~m} / \mathrm{s}$, giving a variability of $0.6 / 6.1=$ 0.10 , or $10 \%$. Although confidence in the average wind speed is low, this variability implies that the annual average wind speed will fall within $+/-30 \%$ (3 standard deviations) $99 \%$ of the time, assuming these values are normally distributed. 
The historical 32 year anemometer locations changed several times for this collection of historical wind data; therefore, there were different sensors, mountings, heights, exposures, and possibly drifting calibrations. The heights varied from $4.6 \mathrm{~m}$ to $19.8 \mathrm{~m}$, so each year's data was adjusted to the NREL study's measurement height $(30.5 \mathrm{~m})$ using the $1 / 7$ power law. These low heights are more susceptible to the effects of obstructions.

Readings on the historical data generally were made 12-18 times a day -- more often in the daytime -- thereby raising the possibility of skewing the averages with non-uniform intervals. Some bias toward lower wind speed measurements might be expected if more readings occurred in daytime, if unknown obstructions were present, or if old anemometers began to bind. Because these factors are not tractable, no attempt is made to account for them. Therefore, the averages found here will not be used for the hybrid system modeling later in this report, but the interannual variability of $10 \%$ will be used for a sensitivity analysis.

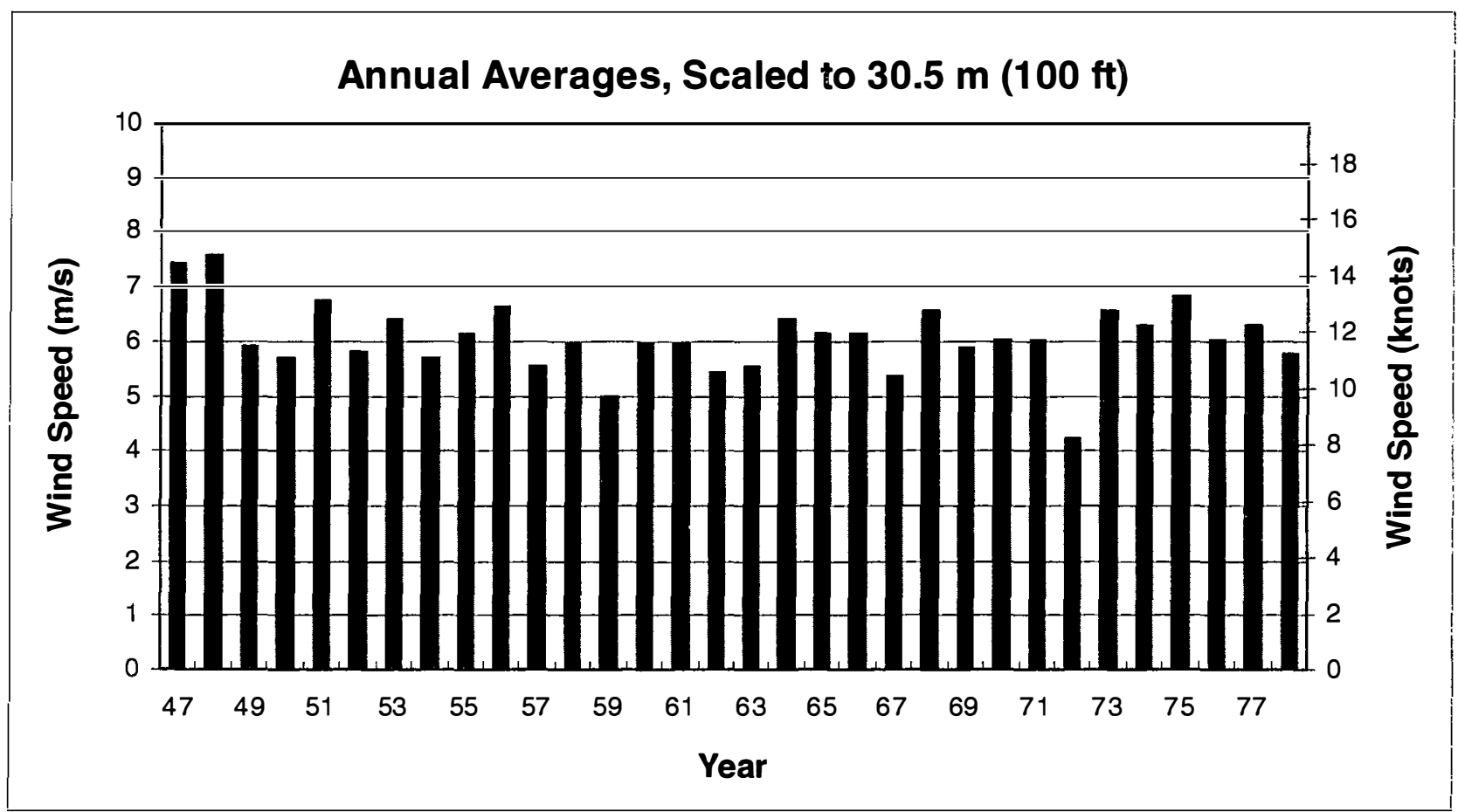

Figure 9: SNI Historical Wind Speeds

\subsection{Current Wind Data}

Statistical analysis of the full year of NREL 10 minute data yielded the results shown in Table 3, and a full wind speed distribution is presented in Figure 10. Collected at $30 \mathrm{~m}$ height under highly controlled conditions, this data will be used in hourly form for the subsequent hybrid system modeling. 
Table 3: Summary of Current SNI Meteorological Data

\begin{tabular}{lccccc} 
Channel & Units & Average & $\begin{array}{c}\text { Standard } \\
\text { Deviation }\end{array}$ & Minimum & Maximum \\
\hline Wind Speed & $\mathrm{m} / \mathrm{s}$ & 7.2 & 4.8 & 0.0 & 28.5 \\
Wind Speed & $\mathrm{knots}$ & 14.0 & 9.3 & 0.0 & 55.4 \\
Ambient Temperature & ${ }^{\circ} \mathrm{C}$ & 14.5 & 3.9 & 6.4 & 33.4 \\
Ambient Pressure & $\mathrm{mbar}$ & 983 & 4.6 & 965 & 997 \\
Air Density & $\mathrm{kg} / \mathrm{m}^{3}$ & 1.20 & 0.02 & 1.14 & 1.22 \\
Power Density & $\mathrm{W} / \mathrm{m}^{2}$ & 473 & 759 & 2.3 & 4010
\end{tabular}

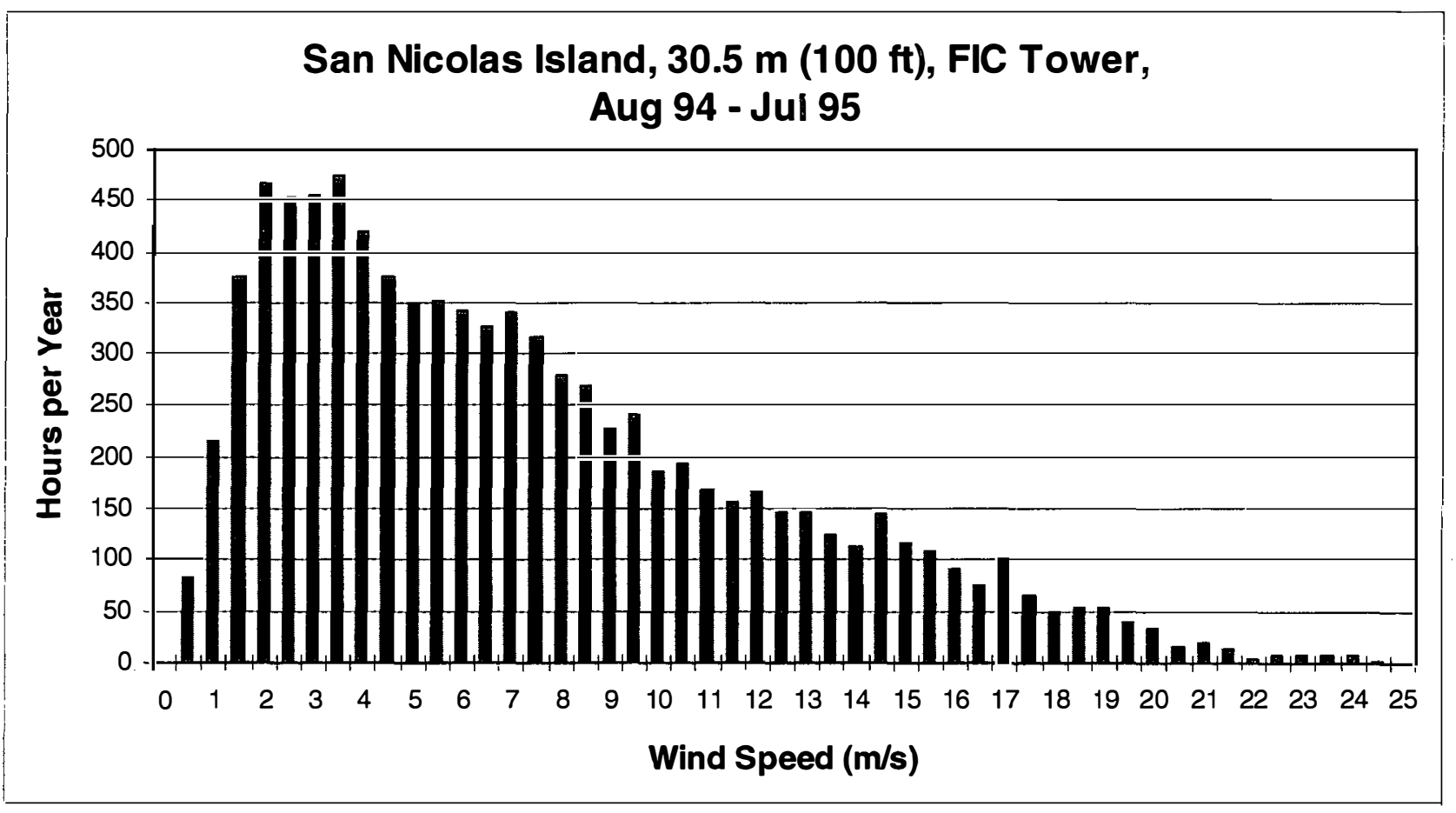

Figure 10: SNI Wind Speed Frequency Distribution

An annual record using monthly average wind speeds is plotted in Figure 11. February appears to be the low month, with a high month in April just two months later. The rest of the year is between 6 and $8 \mathrm{~m} / \mathrm{s}$ more consistently. The source data was derived from NREL testing on SNI at $30.5 \mathrm{~m}$ at Facility 186 for the period 1 August 1994 through 31 July 1995. The annual average diurnal given in Figure 12 shows a stable pattern, with wind speeds falling between 6 and $8 \mathrm{~m} / \mathrm{s}$. However, these are averages, any specific day could be quite different. For reference, the column labeled " 0000 " refers to the first hour of the day, 0000 to 0100 . 


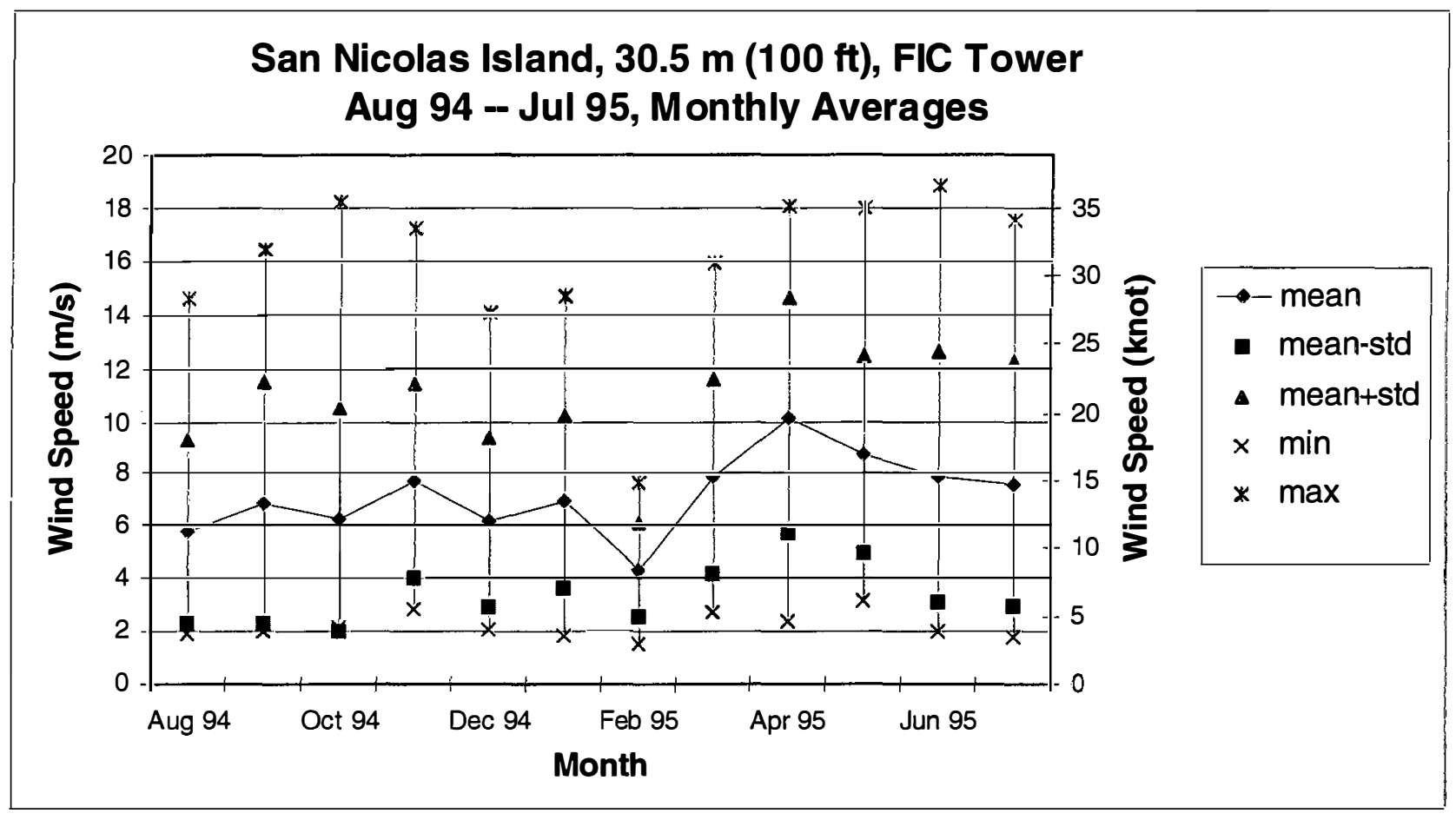

Figure 11: SNI Annual Wind Speed Record

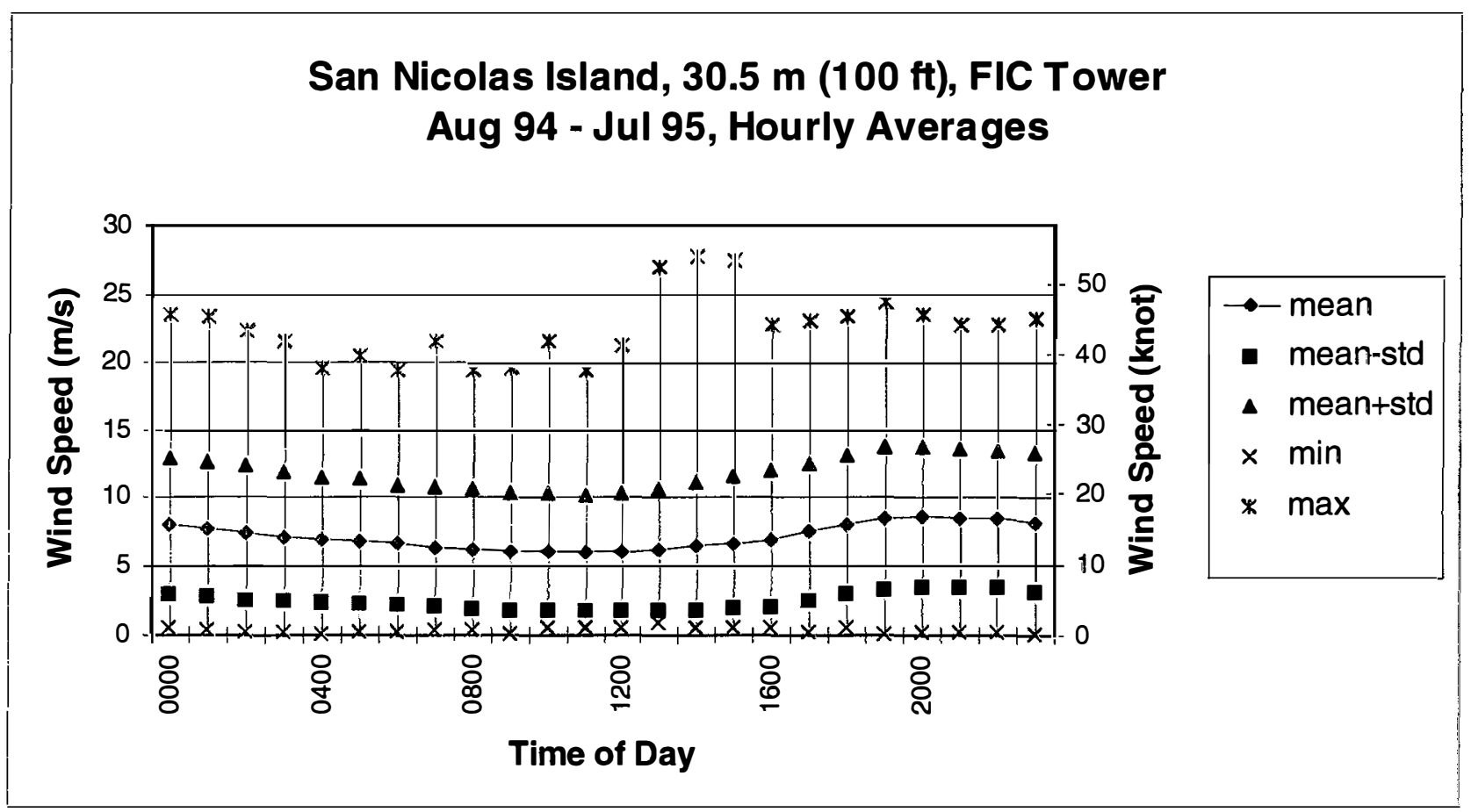

Figure 12: SNI Annual Average Diurnal Wind Speed 


\subsection{PROPOSED ENERGY SYSTEM AND ANALYSIS}

A hybrid energy system consisting of combined wind and diesel generators may be economically and environmentally advantageous for SNI and surrounding areas. A preliminary study of such a system was conducted using a spreadsheet program to compare the cost of power generation for the current baseline (diesel only) to several hybrid cases. The hybrid cases were compared to determine the most cost-effective number of wind turbines to purchase.

\subsection{Hybrid System}

The proposed hybrid system is relatively simple. Between one and four commercially available wind turbines (each with a capacity of $225 \mathrm{~kW}$ ) would be combined with the existing $3500 \mathrm{~kW}$ diesel generation capacity. With a demand peak of $1230 \mathrm{~kW}$, no more than $1500 \mathrm{~kW}$ of diesel is on line at any time. Therefore, wind penetration of "on-line" capacity with four wind turbines is $900 / 1500=60 \%$. Based on instantaneous power, wind penetration can range from $0 \%$ when there is no wind to $250 \%$ when peak wind power of $900 \mathrm{~kW}$ is combined with a minimum load of 360 $\mathrm{kW}$.

Power storage, photovoltaic generation, dump load, and advanced load management were not included in this preliminary analysis. Their consideration in future analyses may be useful.

Several assumptions were made regarding the power that can be generated by the wind. First, at least $200 \mathrm{~kW}$ must always be generated by the existing diesel generators even if there is excess wind capacity. Second, it is assumed that only the necessary number of turbines will be generating power at any given time, with the remaining turbines idled. Third, a minimum diesel run time is required to hold the number of diesel starts on the order of 100 . To simulate this in real operation, the diesel rating is selected to cover the maximum demand of the previous 30 hours, thereby preventing the diesel from being started too often.

\subsection{Diesel Generation}

As mentioned in Section 2.3, there are five diesel generator sets, two generators rated by the Navy at $500 \mathrm{~kW}$, two at $750 \mathrm{~kW}$, and one at $1000 \mathrm{~kW}$. One generator of each size is included in the hybrid system model. The generator fuel/energy curves were given in Section 2.3. Typically, only one diesel is run at a time, unless a special naval exercise requires $1250 \mathrm{~kW}$ capacity.

The power demand for 1 year ranges from a minimum of $360 \mathrm{~kW}$ to a maximum estimated at 1472 $\mathrm{kW}$. The fuel needed (with no wind energy input) is calculated based on minimizing the number and rating of operating diesel generators. The power demand can be met by configuring the diesels to produce $500,750,1000,1250$ or $1500 \mathrm{~kW}$.

The diesel generators follow the load automatically through speed and frequency monitoring and fuel rate regulation. The diesels have no specific selection priority, but there are other constraints. At least one diesel must be on line at all times to ensure reliable capacity and system stability; the minimum operating load is $200 \mathrm{~kW}$, or $40 \%$ rated power for the smallest unit. 
Also, according to SNI power system operating data from 1989/90, the manual operating scheme tends to favor running the larger engines for long periods of time, so that the actual number of diesel starts was about 127 for the year, as estimated from the Navy-supplied data. An optimized operating scheme alone could provide significant fuel savings, but it would require many more diesel starts and some form of automated system control. For this study, the spreadsheet model follows the actual manual operating scheme for all cases, wind and baseline. The hybrid wind systems likely would show even greater savings than the baseline system with such an optimizer.

\subsection{Wind Generation}

The wind generation system modeled consists of between 1 and 4 commercial wind turbines rated at $225 \mathrm{~kW}$ each. The sea level power curve for this turbine is shown in Figure 13. A fifth-order polynomial was fit to the curve for use in the spreadsheet model. No density correction was made to the power curve, as the proposed wind site is only 700 to $800 \mathrm{ft}$ above sea level. The wind turbines can be curtailed (shut down) as necessary when excess wind energy is available.

The net annual energy production (AEP) can be computed by multiplying the power production level by the number of hours for each wind speed level and summing the results. If $P_{i}$ is power and $\mathrm{N}_{\mathrm{i}}$ is number of hours at each wind speed, then:

$$
\operatorname{AEP}=\operatorname{sum}\left(\mathrm{P}_{\mathrm{i}}{ }^{*} \mathrm{~N}_{\mathrm{i}}\right), \quad \mathrm{i}=0.0,0.5,1.0, \ldots 100.0 \mathrm{~m} / \mathrm{s} .
$$

Actual AEP is often lower because of various system losses. Assessment of the wind site showed that there are not any significant obstructions to the prevailing wind flow. Also, there is plenty of room for one to four wind turbines, so array losses should be mitigated with proper siting. However, other sources of loss cannot be avoided as easily. Such losses include $1-5 \%$ availability loss for operation and maintenance, possibly $5 \%$ for blade soiling losses, $2 \%$ for turbulence losses, and 3\% for control, grid, and collection system losses. Using $97 \%$ availability, the combination of these sources is significant, having a net loss of $11.5 \%$. To account for these losses, the wind turbine power curves have been penalized by $11.5 \%$ throughout their range. 


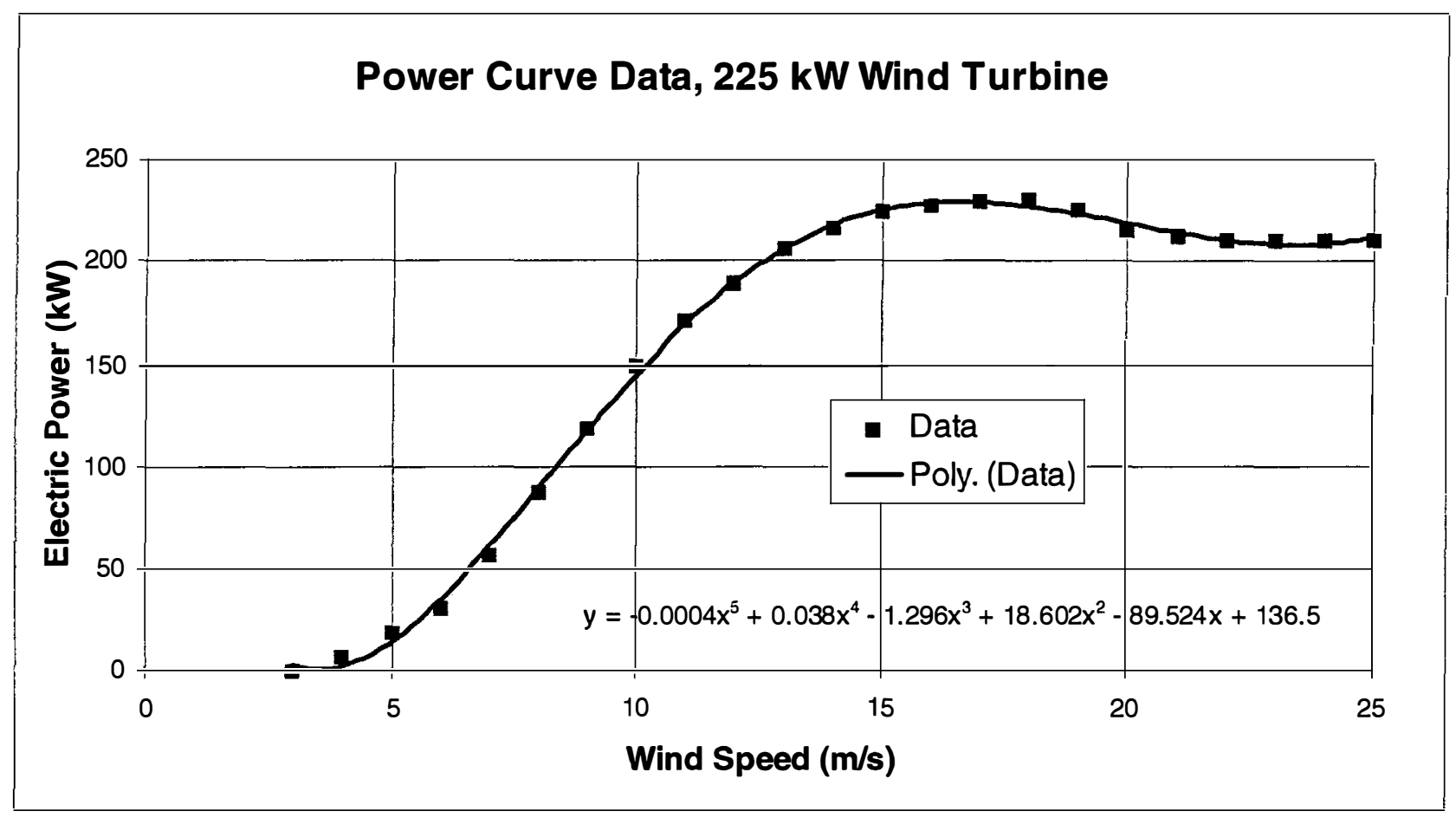

Figure 13: Power Curve, 225 kW Wind Turbine

\subsection{Load Profile}

The hourly SNI load data mentioned in Section 2.4 was used in the hybrid system model. The evidence of the power production statistics in Section 2.3 indicates that the loads at SNI had grown $19.66 \%$ from the $1989 / 90$ load data year to 1995 , so these values were inflated accordingly and rearranged to a calendar year for the hybrid modeling. The uninflated load frequency distribution was shown earlier in Figure 4.

Short-term load variability is defined as 0.044 based on the following rationale: The average load, $771 \mathrm{~kW}$, gives 1 sigma $=34 \mathrm{~kW}$ and 3 sigma $=102 \mathrm{~kW}$. These fluctuations coincide with operating experience, which has demonstrated a 20 - $30 \mathrm{~kW}$ normal fluctuation and an occasional $100 \mathrm{~kW}$ spike during a motor start. The hybrid spreadsheet model accommodates this fluctuation by reserving a $100 \mathrm{~kW}$ margin of diesel capacity above the net demand for each 30 hour period. 


\subsection{Wind Profile}

The hourly wind speed averages from 1 August 1994 through 31 July 1995 (from the new NREL / SNI data set) were used in the hybrid system model. As with load, this data was rearranged to a calendar year to assure proper synchronization with the load profile. The wind frequency distribution was presented earlier in Figure 10. Annual and monthly diurnal wind speed and load are overlaid in Figure 14. Although in the same range, they appear to be inversely correlated through the day.

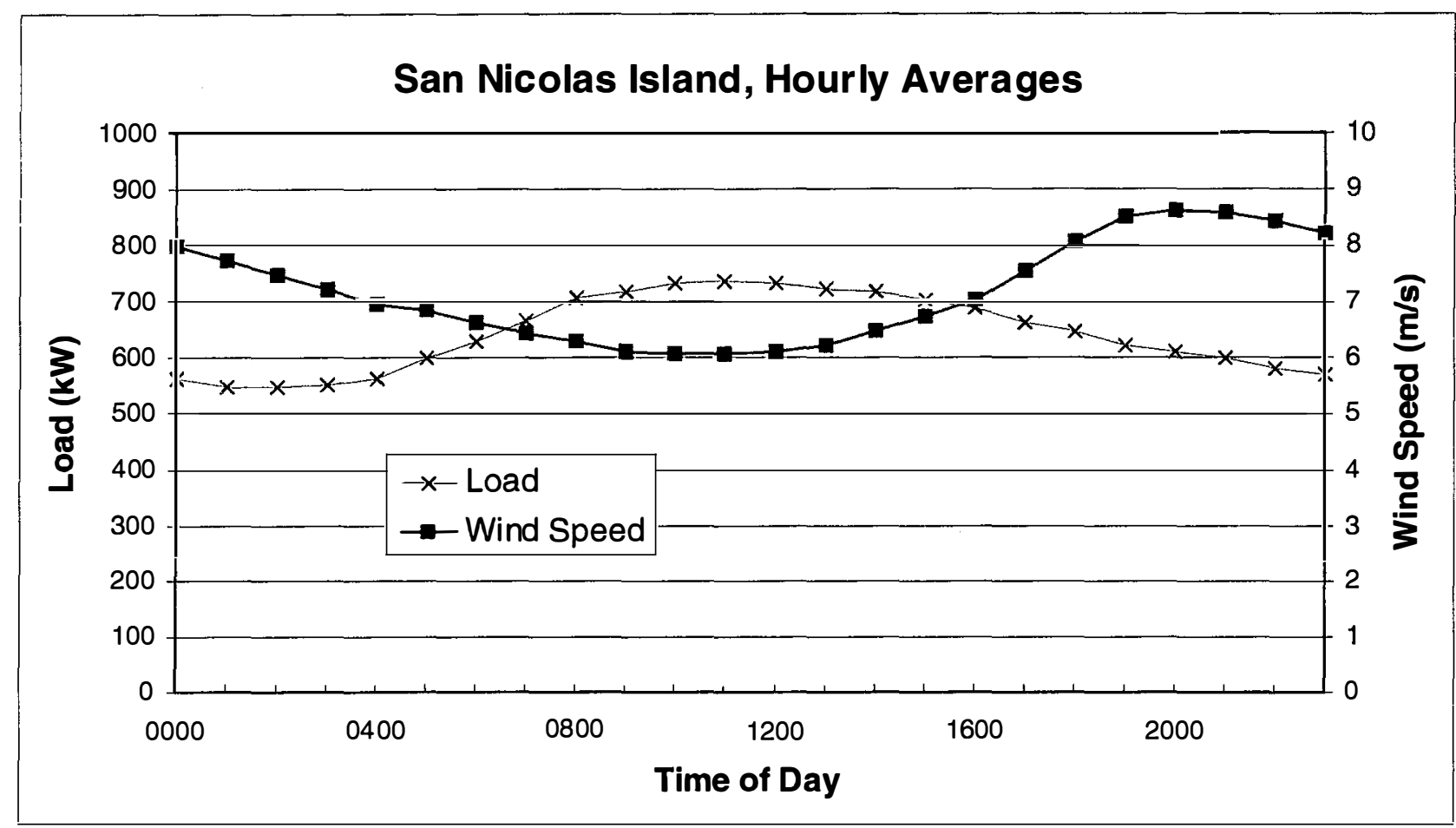

Figure 14: SNI Diurnal Load and Wind Speed Overlay

\subsection{Hybrid System Spreadsheet Model}

The hybrid system model uses the existing diesel system plus new wind generation; the load data is scaled to 1995 and the wind data is from the NREL/SNI 1994-1995 measurements. The spreadsheet model starts by calculating a diesel rating that covers the demand with sufficient margin to ensure a minimum diesel run time of 30 hours and handle $100 \mathrm{~kW}$ excursions. The minimum run time holds the number of starts to less than 130 per year. Diesel consumption, based on demand and efficiency, is calculated next. Finally, the number of diesel starts and run time are computed.

The wind-hybrid section follows by calculating the power produced by a single wind turbine at each hour of the year. Then it calculates the optimal wind power usage by choosing the greatest 
number of turbines to operate, without exceeding demand, while maintaining at least $200 \mathrm{~kW}$ of diesel energy online. This wind power, when subtracted from the demand, reduces the amount of power required from the diesel generators. Only in very low or very high winds is the diesel power demand unchanged. Diesel fuel consumption is then calculated from this net demand and fed into the fuel savings over the diesel-only system.

Four different cases of the hybrid system were examined. The results are summarized in Table 4. In the first case, just one $225 \mathrm{~kW}$ wind turbine was added to the existing (baseline) diesel set-up, in the second case two $225 \mathrm{~kW}$ turbines, and so on, up to four $225 \mathrm{~kW}$ wind turbines. The minimum and maximum net loads (demand minus wind power) are $0 \mathrm{~kW}$ (loss of grid) and $1472 \mathrm{~kW}$ for all cases. The number of diesel starts is determined by incrementing a counter every time the diesel capacity changes. The diesel run time is 8760 hours (1 diesel all year), plus the number of hours at $1250 \mathrm{~kW}$ capacity ( 2 diesels on). The diesel-only case required 100 starts and 15,491 hours of total run time for the year. 
Table 4: 1995 Hybrid Systems vs. Baseline:

Spreadsheet Model Results

\begin{tabular}{|c|c|c|c|c|c|c|}
\hline \multicolumn{2}{|l|}{ Hybrid Results } & $\begin{array}{r}\text { Baseline } \\
\text { Diesel } \\
\text { Only }\end{array}$ & $\begin{array}{l}1 \text { Wind } \\
\text { Turbine } \\
225 \mathrm{~kW}\end{array}$ & $\begin{array}{r}2 \text { Wind } \\
\text { Turbines } \\
225 \mathrm{~kW} \\
\end{array}$ & $\begin{array}{r}3 \text { Wind } \\
\text { Turbines } \\
225 \mathrm{~kW} \\
\end{array}$ & $\begin{array}{r}4 \text { Wind } \\
\text { Turbines } \\
225 \mathrm{~kW}\end{array}$ \\
\hline Average WS, 1 yr. & $\mathrm{m} / \mathrm{s}$ & 7.2 & 7.2 & 7.2 & 7.2 & 7.2 \\
\hline Average Load, 1 yr. & $\mathrm{kW}$ & 771 & 771 & 771 & 771 & 771 \\
\hline Run Duration & hour & 8,760 & 8,760 & 8,760 & 8,760 & 8,760 \\
\hline Avg. Net Diesel Loac & $\mathrm{kW}$ & 771 & 704 & 638 & 595 & 569 \\
\hline Energy Demand, 1yr & $\mathrm{MWh}$ & 6753 & 6753 & 6753 & 6753 & 6753 \\
\hline Diesel Energy, 1yr & MWh & 6753 & 6166 & 5593 & 5216 & 4983 \\
\hline Wind Energy, $1 \mathrm{yr}$ & $\mathrm{MWh}$ & 0 & 588 & 1160 & 1538 & 1770 \\
\hline Unused Wind Energy & MWh & 0 & 1 & 17 & 228 & 584 \\
\hline Diesel Energy & $\%$ & 100.0 & 91.3 & 82.8 & 77.2 & 73.8 \\
\hline Wind Energy & $\%$ & 0.0 & 8.7 & 17.2 & 22.8 & 26.2 \\
\hline Wind Energy Increm & ntal Turbine & $\% 0.0$ & 8.7 & 8.5 & 5.6 & 3.4 \\
\hline Wind System Capaci & y Factor \% & $\mathrm{n} / \mathrm{a}$ & 29.8 & 29.4 & 26.0 & 22.5 \\
\hline Wind Sys Inctl Turbi & ne Cap Fac \% & $\mathrm{n} / \mathrm{a}$ & 29.8 & 29.0 & 19.2 & 11.8 \\
\hline Fuel Usage & kltr & 1997 & 1882 & 1770 & 1696 & 1651 \\
\hline Fuel Usage & $\%$ of base & 0.0 & 94.2 & 88.6 & 84.9 & 82.7 \\
\hline Fuel Saving & kltr & 0 & 151 & 311 & 417 & 482 \\
\hline Inctl Wind-produced & $\mathrm{COE}, \$ / \mathrm{kWh}$ & $\mathrm{n} / \mathrm{a}$ & 0.266 & 0.265 & 0.270 & 0.282 \\
\hline Levelized COE & $\$ / \mathrm{kWh}$ & 0.358 & 0.350 & 0.342 & 0.338 & 0.338 \\
\hline COE Saving & $\$ / \mathrm{kWh}$ & 0.000 & 0.008 & 0.016 & 0.020 & 0.020 \\
\hline COE Saving & $\%$ of base & 0.0 & 2.2 & 4.5 & 5.6 & 5.6 \\
\hline Payback Period & year & $\mathrm{n} / \mathrm{a}$ & 5.22 & 5.29 & 6.00 & 6.97 \\
\hline Internal Rate of Retur & $\mathrm{n}, \%$ & $\mathrm{n} / \mathrm{a}$ & 18.5 & 18.2 & 15.8 & 13.1 \\
\hline
\end{tabular}

Notes: (1) "Net Load" means net power required from the diesels, or system load minus useable wind power.

(2) Wind System Capacity Factor = Wind Energy [MWh] / (\#turbines*rating[0.225MW]*8760[h]).

(3) Inctl wind-produced Cost of Energy (COE) $=$ (hybrid COE*energy demand - baseline COE*diesel energy) / wind energy.

(4) All other values derived from spreadsheet model results, Appendix A.

Four $225 \mathrm{~kW}$ wind turbines reduce diesel energy production by $26.2 \%$ and fuel consumption by $17.3 \%$. Two $225 \mathrm{~kW}$ wind turbines reduce diesel energy production by $17.2 \%$ and fuel consumption by $11.4 \%$. Fuel savings fall below energy savings because the high wind variability necessitates greater diesel capacity running at somewhat less efficient conditions. However, these fuel savings could be improved significantly if the diesel usage was optimized, but at the cost of starting and stopping the engines much more frequently. 


\subsection{HYBRID2 Model}

The hybrid system was also modeled using HYBRID2, a software package for operational and economic modeling of complex hybrid energy systems. The same input data was used in both the spreadsheet and HYBRID2 models. A description of the software package follows.

The HYBRID2 code was developed by the University of Massachusetts and the NREL to elucidate the performance of a variety of wind/diesel and hybrid power system configurations. HYBRID2 is a combined probabilistic/time series model designed to study a wide variety of hybrid power systems. The hybrid systems may include diesel generators, wind turbines, battery storage, different power conversion devices and a photovoltaic array. Systems can be modeled on the AC, DC or multiple buses. A variety of different operating strategies have been allowed.

Of two types of simulation models for hybrid systems that are widely used, the first are known as "logistic" models. These models are used primarily to predict long-term performance and to provide input to economic analyses. Historically, most of these logistic models have been of the time series type. The second type of models are called "dynamic" models and consider very rapid fluctuations and system responses to changes in system parameters. HYBRID2 is a logistic model that uses statistical analysis to more accurately model what occurs during a given time step. The HYBRID2 code can model systems with time series input data ranging from 5 minutes to 2 hours. The original version of the model, HYBRID 1, is described in Manwell, et al. [7]. Briefly, HYBRID2 was designed to provide a consistent platform for comparing a variety of wind/diesel hybrid power systems, a means of performance estimation for feasibility studies, a baseline for comparison with other models, and insight into control system options.

The types of systems that can be modeled include those with (1) up to seven different types of diesel generators, (2) up to 60 wind turbines of different types, (3) storage batteries, (4) four types of power conversion, (5) dump load, (6) solar photovoltaics. The model uses a statistical approach to account for the effect of short term fluctuations in wind power and load, and to consider the power smoothing effect of multiple wind turbines. The spacing between turbines in a multiturbine system is also considered. Many different control strategies and options are included that allow for minimum diesel operating power levels, diesel "back drive" using the diesel as a limited dump load, minimum diesel run time, as well as other specialized control and dispatching options. Outputs include, where applicable, useful wind and solar energy, diesel energy, diesel operating hours and start/stops, diesel fuel use, storage system energy losses, and battery life. A very detailed economic analysis is also available that considers new or retrofit systems, operation and maintenance costs, equipment overhaul costs, installation costs, taxes, and system salvage value [8]. Economic module outputs include, but are not limited to, life-cycle costing, project cash flow, and investment payback. The verification of the HYBRID2 code is ongoing, but very positive. Comparisons are being made to a number of operational hybrid power systems as well as to independent testing. The HYBRID2 code is also heavily based on its predecessor, HYBRID1, which has been validated [9]. HYBRID2 instructions are available in Manwell, et al [10]. 


\subsection{ENERGY COST ANALYSIS}

\subsection{Methodology}

After estimating 1995 operating costs for the four cases of the hybrid system and for the baseline diesel-only system, the resulting levelized costs of energy (COE) were compared. Also, payback periods were computed for the four cases of hybrid system investment. COE is derived using

$$
\mathrm{COE}=\mathrm{NPV} * \mathrm{CRFI} / \mathrm{AEP},
$$

where NPV is the total net present value of all system costs, CRFI is the capital recovery factor for system income, and AEP is annual energy production (system load). A simple payback period is calculated by dividing the total initial capital cost by the annual savings from system operation, which includes the difference in fuel, overhaul, and operations and maintenance (O\&M) costs between the hybrid and baseline systems [6].

Economic assumptions included 3\% general inflation, $4 \%$ fuel inflation, $6.9 \%$ discount rate, 20 year system life, and $100 \%$ down payment on new investment. These values have been confirmed by NFESC personnel as reasonable. Although new wind turbines will start with a 20 year life, the existing diesel systems have been in service for several years and have limited lives of their own. This is covered by a fund for major diesel overhauls. It was further assumed that no additional labor would be required to operate the hybrid plant beyond that already assigned to operate the existing diesel power plant.

\subsection{Existing System Costs}

Since the baseline system is already in place, it has no initial costs. Its main operating costs are $\$ 1.14 /$ gal for fuel, $\$ 250,000$ per year for the diesel overhaul fund, and about $\$ 0.14 / \mathrm{kWh}$ for O\&M, based on the Navy-provided actual cost items listed in Table 5. These costs are treated in two separate categories. Fixed costs are annual costs that are independent from the amount of diesel usage. Variable costs scale up or down with the amount of diesel energy produced in the year. Fuel costs $\$ 0.3012$ per liter ( $\$ 1.14$ / gal). The SNI Public Works Center schedules major overhauls and covers these in the Navy budget by setting aside a fixed $\$ 250,000$ each year, regardless of diesel usage. 
Table 5: Diesel Operations and Maintenance Costs

\begin{tabular}{crcr} 
Item & Cost & Type & Totals \\
Fixed O\&M Costs: & & & \\
\hline Operations $($ labor $)$ & $\$ 298,043$ & Fixed & \\
Maintenance & $\underline{166,909}$ & Fixed & $\underline{464,952}$ \\
Variable O\&M Costs: & & & \\
\hline Maintenance & 166,909 & Variable & \\
Barge cleaning & 250,000 & Variable & \\
O\&M materials & $\underline{75,000}$ & Variable & $\underline{491,909}$ \\
& & & \\
O\&M Rate & $\$ \underline{0.1417 / \mathrm{kWh}}$ & Total: & $\$ \underline{956,861}$
\end{tabular}

\subsection{Hybrid System Costs}

Hybrid system costs include the baseline costs as given above, plus new costs associated with the wind turbines and interconnect and control equipment. The interconnect and control equipment are included with the wind turbine balance of station (BOS) costs, along with foundations, installation, spare parts inventory, site surveying and preparation, $O \& M$ facilities and equipment, permits and licenses, project management and engineering, and construction insurance and contingency. BOS costs are detailed in Table 6. (Note: It may be possible to further reduce installation and operation costs by adding Department of Defense excess heavy equipment (e.g., a crane) to SNI inventory.)

Each sample wind turbine costs $\$ 250,000$. An additional $\$ 87,500$ is required to cover BOS costs. Thus, the total capital cost required for four wind turbines is $\$ 1.35 \mathrm{M}$. Overhaul costs are fixed at an annual $\$ 1000$ per wind turbine, regardless of turbine usage. Actual wind turbine O\&M costs of $\$ 0.01 / \mathrm{kWh}$ are doubled to $\$ 0.02 / \mathrm{kWh}$ to account for the small system size and the extra burden SNI represents with its remote setting. As implied by its units, this O\&M cost is variable, or fully dependent on wind turbine usage. These amounts are based on working systems using the sample $225 \mathrm{~kW}$ wind turbine. 
Table 6: Balance of Station for Four $225 \mathrm{~kW}$ Wind Turbines

\begin{tabular}{llrr} 
Item & Estimate (Source) & $\begin{array}{r}\text { Additional } \\
\text { SNI Cost }\end{array}$ & $\begin{array}{r}1995 \\
\text { Cost }\end{array}$ \\
\hline Electrical Collection System & 34,000 (NREL [6]) & & $\$ 34,000$ \\
Control \& Monitoring Equipment & 12,000 (NREL) & 10,000 & 22,000 \\
Foundations & 30,000 (NREL) & 6,000 & 36,000 \\
Installation & 20,000 (NREL) & 4,000 & 24,000 \\
Spare Parts & $1 \%$ turbine (NREL) & & 13,500 \\
Site Survey \& Preparation & 9,000 (NREL) & 2,500 & 11,500 \\
Permits \& Licenses & 10,000 (SNI add on) & & 10,000 \\
Environmental Assessment & 10,000 (SNI add on) & & 10,000 \\
Project Management \& Engr. & $9 \%(3-15 \%$ NREL, mfg.) & & 121,500 \\
Construction Ins \& Contingency & $5 \%(3-10 \%$ NREL, govt.) & & 67,500 \\
$\quad$ Total & & & $\$ 350,000$
\end{tabular}

\subsection{Hybrid System Spreadsheet Model Savings}

Once all of the engineering and cost data were ready, an economic assessment was performed. Figure 15 shows the resulting COE decreasing as the number of wind turbines increases. The trend has leveled off with four turbines, and it will probably reverse and start to increase, as each additional wind turbine would be less efficiently utilized because of the growing wind energy penetration combined with a lack of system storage. For this same reason, Figures 16 and 17 show the payback period growing and the internal rate of retum declining after similar values for one and two wind turbines. The complete economic tables can be found in Appendix A. These results are provided for those who need data points to check their own simulations. Copies of the spreadsheets used here can be obtained from the authors.

The $\$ 1.35 \mathrm{M}$ capital investment in the four-turbine-hybrid system was easily offset by savings in fuel, overhaul, and O\&M costs for diesel operation of $\$ 194,000$ annually, giving a 6.97 year simple payback period with $13.1 \%$ internal rate of retum and dropping the COE from $\$ 0.358 / \mathrm{kWh}$ to $\$ 0.338 / \mathrm{kWh}$. This would give net savings of $\$ 0.020 / \mathrm{kWh}$, or $\$ 135,000$ in 1995 . Two $225 \mathrm{~kW}$ wind turbines have annual operating savings of $\$ 128,000$, and would give a 5.29 year payback period, $18.2 \%$ internal rate of retum, and $\$ 0.342 / \mathrm{kWh}$ COE, with net savings of $\$ 0.016 / \mathrm{kWh}$, or $\$ 108,000$ in 1995. 


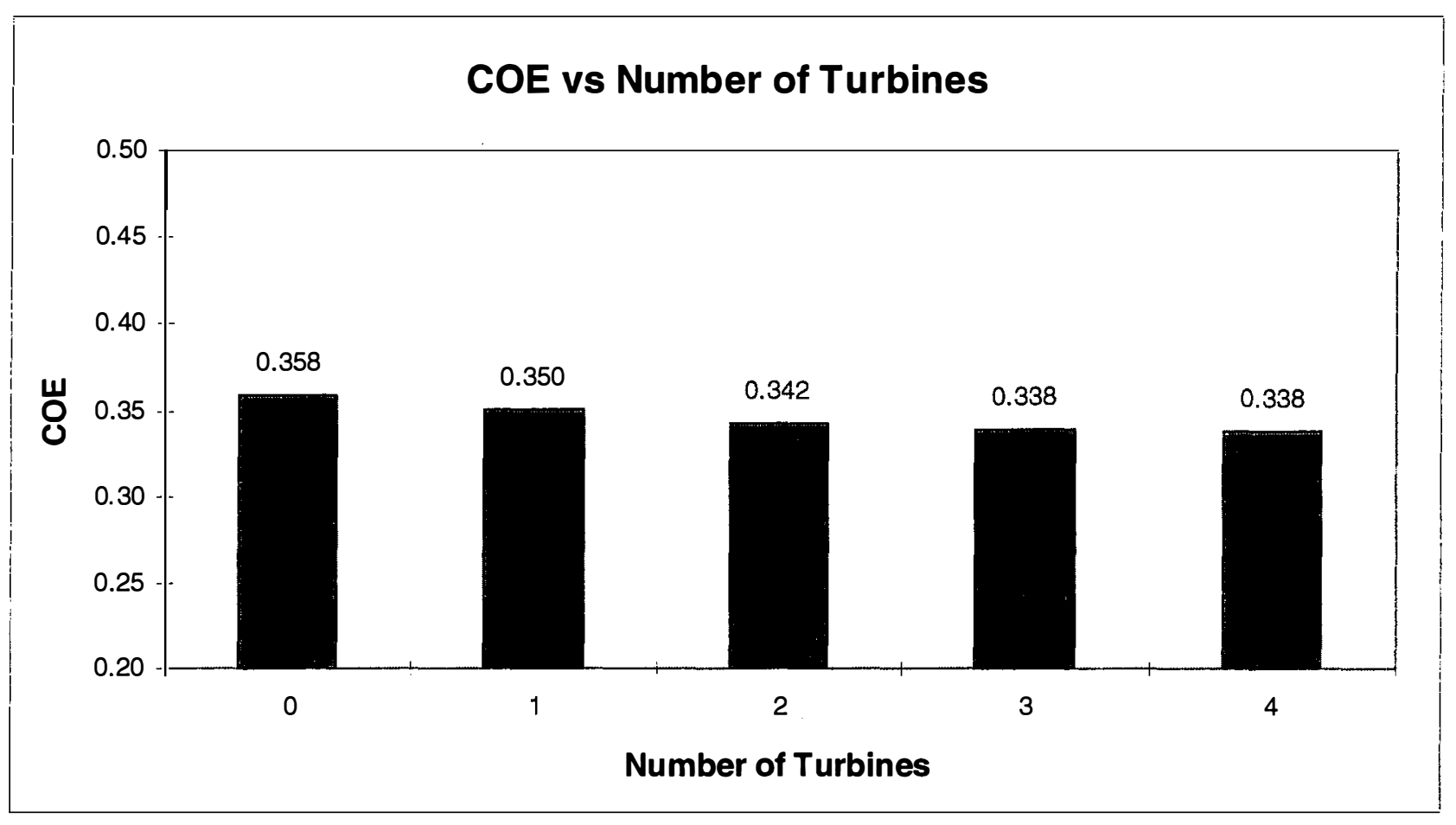

Figure 15: COE vs. Number of Wind Turbines

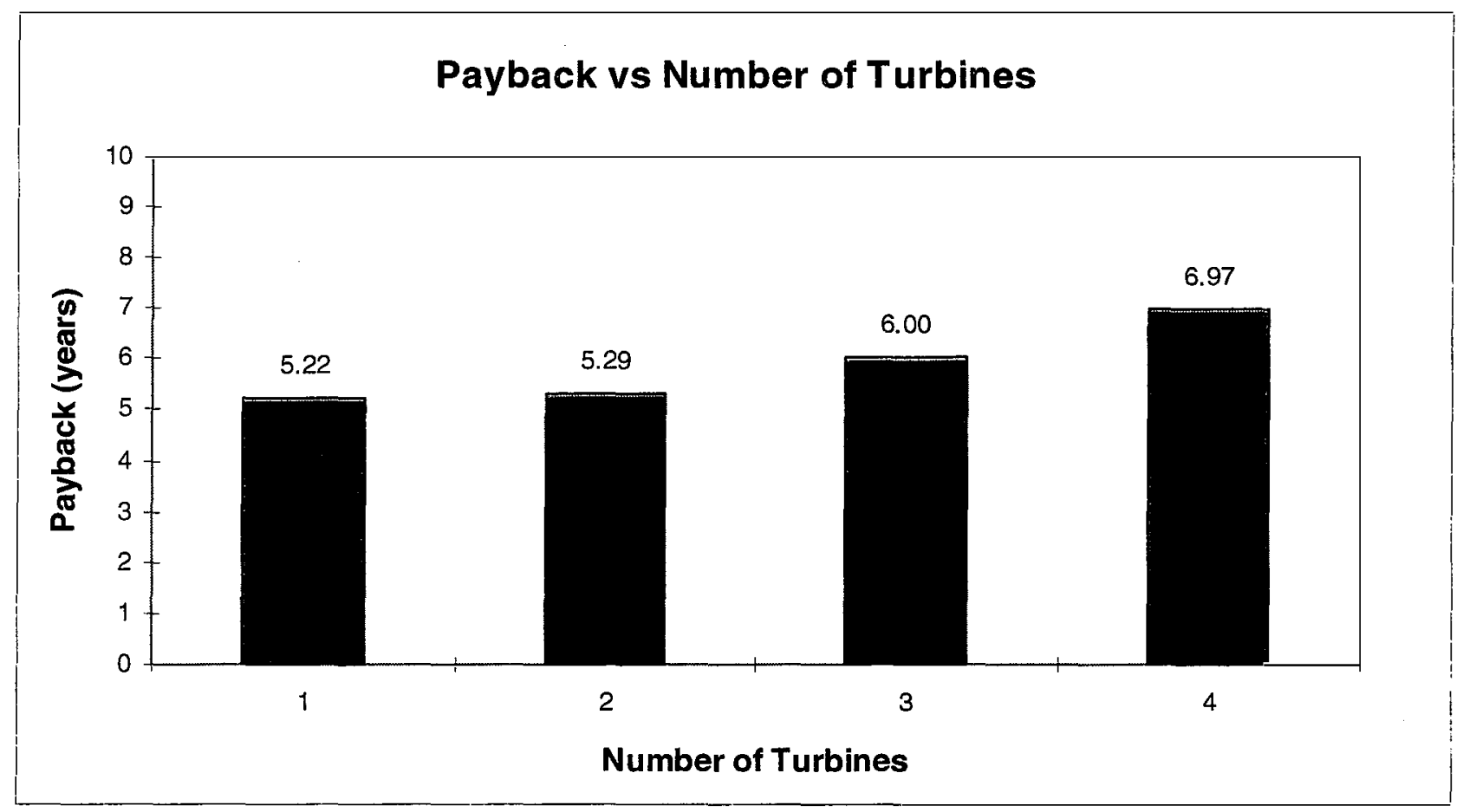

Figure 16: Payback Period vs. Number of Wind Turbines 


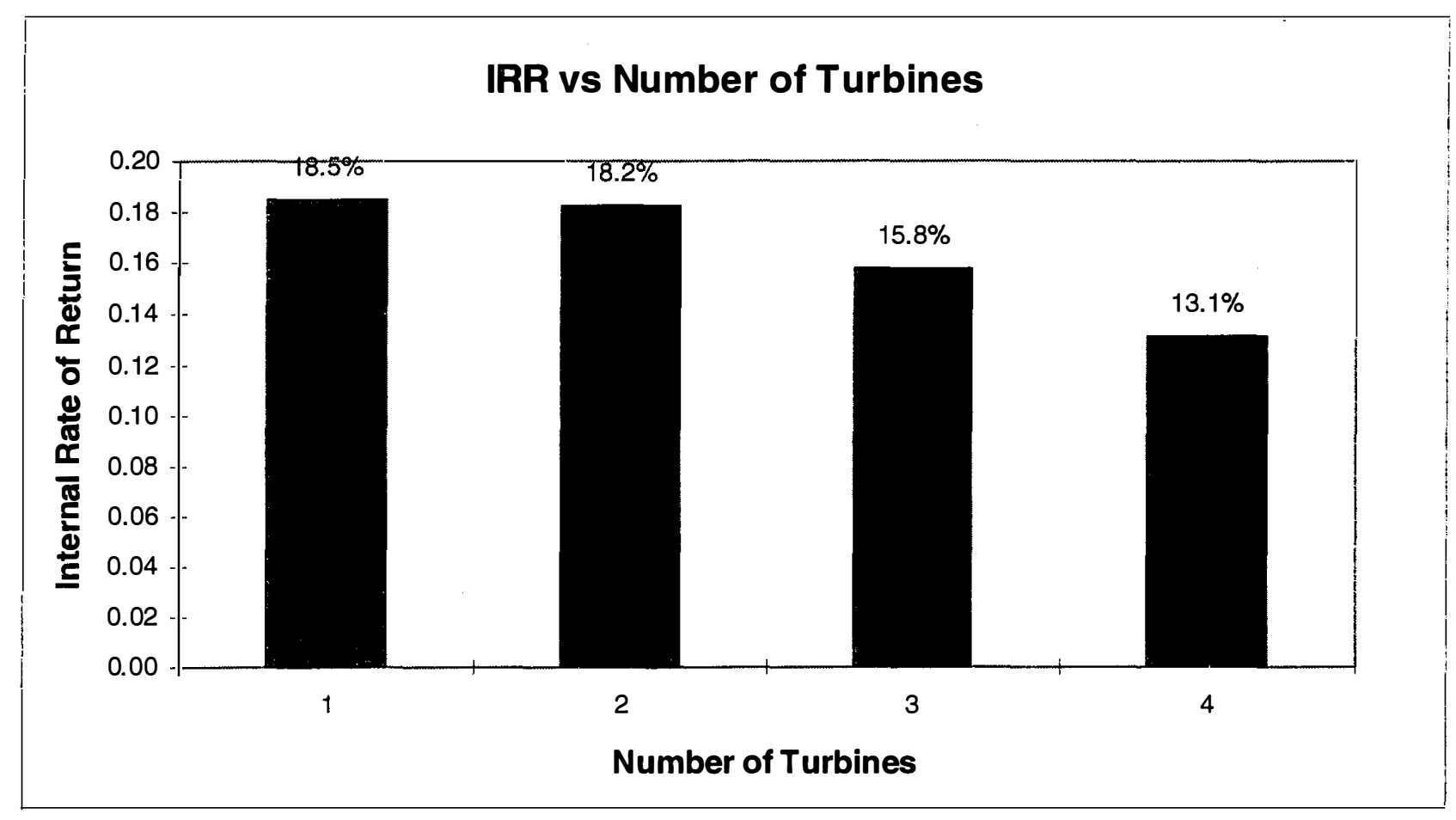

Figure 17: Internal Rate of Return vs. Number of Wind Turbines

\subsection{Wind Speed Sensitivity}

To check the sensitivity of the results to variations in average wind speed from year to year, the two-turbine case was run with the wind speeds adjusted upward and downward by $10 \%$, which is the interannual variability found in the historical wind measurements. The results are shown in Table 7. With the wind speed $10 \%$ lower than the NREL measurement year, COE and payback period rose by $1 \%$ and $17 \%$. With the wind speed $10 \%$ higher, COE and payback period dropped by $1 \%$ and $11 \%$.

Table 7: Economic Sensitivity to Wind Speed Variations Spreadsheet Model for 2 Turbines

\begin{tabular}{lccccc} 
Case & Wind Speed & $\begin{array}{c}\text { Diesel } \\
\text { Saving } \\
(\mathrm{kltr})\end{array}$ & $\begin{array}{c}\text { Cost of } \\
\text { Energy } \\
(\$ / \mathrm{kWh})\end{array}$ & $\begin{array}{c}\text { Payback } \\
\text { Period } \\
\text { (years) }\end{array}$ & $\begin{array}{c}\text { Internal } \\
\text { Rate of } \\
\text { Return }(\%)\end{array}$ \\
\hline minus 10\% & $6.5 \mathrm{~m} / \mathrm{s}$ & 195 & 0.346 & 6.2 & 15.2 \\
baseline & $7.2 \mathrm{~m} / \mathrm{s}$ & 227 & 0.342 & 5.3 & 18.2 \\
plus 10\% & $7.9 \mathrm{~m} / \mathrm{s}$ & 256 & 0.339 & 4.7 & 20.9
\end{tabular}




\subsection{HYBRID2 Model Savings}

Results from the HYBRID2 model generally are consistent with the spreadsheet model used for this study. With two $225 \mathrm{~kW}$ turbines, HYBRID2 gives a simple payback period of 4.43 years; with four $225 \mathrm{~kW}$ turbines, the payback is 7.21 years. The shorter payback time with two turbines (4.43 instead of 5.29 in the spreadsheet model) likely results from using automatic operation of the diesel generation system in HYBRID2, whereas the spreadsheet model simulates manual operation. Indeed, the HYBRID2 model results in 394 diesel starts; the spreadsheet model 100 starts, which is slightly below the 127 starts reported in the actual 1989/90 SNI Navy data. The longer payback time with four turbines ( 7.21 instead of 6.97 in the spreadsheet model) is likely caused by HYBRID2's lack of a provision for curtailing excess wind energy, which increases the O\&M costs attributed to wind turbine operation. Complete Hybrid 2 model spreadsheet results are available on request from the authors, and can be obtained through NREL. 


\subsection{CONCLUSIONS}

SNI has an excellent wind resource, with an annual average wind speed of $7.2 \mathrm{~m} / \mathrm{s}$ (14.0 knots) as measured by NREL at $30.5 \mathrm{~m}$ (100 ft) at Facility No. 186 in the August 1994 - July 1995 data collection period. Recognizing this, a hybrid energy system was modeled to examine the merits of supplementing the existing diesel generators with a modest portion of wind energy generation. Using conservative assumptions (unfavorable to wind energy) at every step in the spreadsheet model, the hybrid system displayed favorable operation and economics. The levelized $\mathrm{COE}$ for the hybrid case using four $225 \mathrm{~kW}$ wind turbines is $\$ 0.338 / \mathrm{kWh}$ vs. $\$ 0.358 / \mathrm{kWh}$ for the baseline case. This would create a COE savings of $5.6 \%$. The payback period is 6.97 years, the internal rate of return $13.1 \%$. The two turbine case had a COE of $\$ 0.342 / \mathrm{kWh}$, saving $4.5 \%$, with a payback period of 5.29 years, and an internal rate of return of $18.2 \%$. The COE for this case is relatively insensitive to annual average wind speed, varying $1 \%$ for a $10 \%$ change in wind speed. But the payback period is quite sensitive to wind speed, varying $11 \%$ to $17 \%$ for a $10 \%$ change in wind speed.

This work presented a preliminary study of a hybrid system using between 1 and 4 wind turbines. For the conditions examined here, it appears wind energy will be cost effective in this application. We believe these conditions are realistic. But certainly many alternatives to these cases merit consideration. For instance, it appears that the wind penetration could be increased, thus producing further, yet diminishing, savings. If greater redundancy is required, larger numbers of smaller turbines could be used. Smaller wind turbines would have similar relative performance as those machines examined here, with slightly higher per-energy costs and a somewhat limited selection.

Moreover, excess electrical energy should not be curtailed or wasted on dump loads; rather, it should be used for beneficial purposes, provided those purposes make economic sense. Within the San Nicolas Island electrical grid, such benefits may be realized by using excess wind energy for deferrable loads such as the SNI reverse osmosis water system, water heating, or space heating.

Different economic assumptions, such as higher and lower inflation, do not appear to have much impact on the results, but they also should be examined. Because cost and savings components are well distributed, there does not appear to be a dominant factor affecting the economic results. Factors that could affect the results include the actual capital and installation costs of the wind equipment, diesel fuel costs, and diesel system O\&M and overhaul costs.

As a preliminary review, this study used 1 hour average wind and load data for the hybrid system modeling, which can give only a general sense of economic tradeoffs. Before making any final decisions about a wind-diesel hybrid electrical generation system, a more detailed analysis is recommended. Dynamic load management should be addressed using load and wind data at shorter intervals ( 2 minute or less) to grasp a more realistic picture of load and wind dynamics. 2 minute wind resource data is available from the NREL 1994-1995 measurements. However, 2 minute load data would need to be obtained. 


\section{REFERENCES}

1. McKenna, E. and Olsen, T. (1996). Wind Resource Assessment: San Nicolas Island, California, NREL/TP-442-20231, National Renewable Energy Laboratory.

2. Dulka, K., et al. (1993). San Nicolas Island and Santa Cruz Island Site Manual, Naval Air Weapons Center Weapons Division.

3. Pal, D. and Smuck, S. (1988). Wind Power Assessment for Offshore Landing Field, San Nicolas Island, CA, TM no 74-88-06, Naval Civil Engineering Laboratory.

4. McKenna, E. (1993). Report on the Visit to DoD - USN Facilities for SERDP Project, Inter-Office Memorandum, National Renewable Energy Laboratory.

5. Elliott, D.L., et al. (1987). Wind Energy Resource Atlas of the United States, DOE/CH10093-4, Pacific Northwest Laboratory.

6. Hunter, R. and Elliott, G. (1994). Wind Diesel Systems, Cambridge University Press.

7. Manwell, J.F.; McGowan, J.G.; Baring-Gould, E.I.; Jeffries, W.Q.; and Stein, W.M. "Hybrid Systems Modeling: Development and Validation", Wind Engineering, (18:5) p. 241, Brentwood, England, Multi-Science Publishing Company, LTD.

8. Baring-Gould, I. (1995). Description of Operation and Inputs for the HYBRID2 Economics Module, National Renewable Energy Laboratory.

9. $\quad$ Baring-Gould, E.I.; Manwell, J.F.; Jeffries, W.Q.; and Stein, W.M. (1994). "Experimental Validation of the University of Massachusetts Wind/Diesel System Simulator Code, HYBRID1", Proceedings of the 13th ASME Wind Energy Symposium, New Orleans, LA.

10. Manwell, J., et al. (1995). HYBRID2 - A Hybrid Power System Simulation Model: Operating Instructions for the "Engine" (Version 0.00, Draft), University of Massachusetts and National Renewable Energy Laboratory. 
APPENDIX A: Hybrid Model and Economic Summary Tables 
SAW NICOLAS ISLAND HYBRID SYSTEM MODEL

Maxumum number of who turbines: 1 .

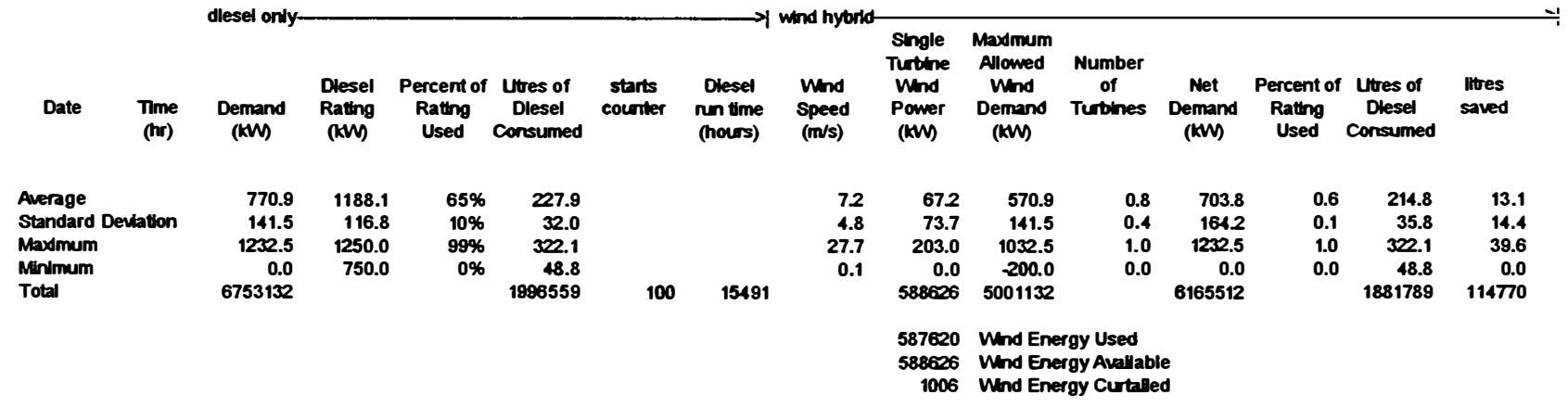

Maxdmum number of Wind turbines: 2

\begin{tabular}{|c|c|c|c|c|c|c|c|c|c|c|c|c|c|c|}
\hline $\begin{array}{l}\text { Time } \\
\text { (hr) }\end{array}$ & $\begin{array}{l}\text { Demand } \\
\text { (kW) }\end{array}$ & $\begin{array}{l}\text { Dlesel } \\
\text { Rathng } \\
\text { (KW) }\end{array}$ & $\begin{array}{l}\text { Percent of } \\
\text { Rating } \\
\text { Used }\end{array}$ & $\begin{array}{l}\text { Utres of } \\
\text { Dlesel } \\
\text { Consumed }\end{array}$ & $\begin{array}{l}\text { starts } \\
\text { coumer }\end{array}$ & $\begin{array}{l}\text { Dlesel } \\
\text { nn time } \\
\text { (hours) }\end{array}$ & $\begin{array}{l}\text { Whd } \\
\text { Speed } \\
(\mathrm{m} / \mathrm{s})\end{array}$ & $\begin{array}{l}\text { Single } \\
\text { Tutthe } \\
\text { Whind } \\
\text { Power } \\
\text { (KW) }\end{array}$ & $\begin{array}{l}\text { Maxdmum } \\
\text { Alowed } \\
\text { Whind } \\
\text { Demand } \\
\text { (KW) }\end{array}$ & $\begin{array}{l}\text { Number } \\
\text { of } \\
\text { Turbines }\end{array}$ & $\begin{array}{l}\text { Net } \\
\text { Demand } \\
\text { (KW) }\end{array}$ & $\begin{array}{l}\text { Percent of } \\
\text { Rathing } \\
\text { Used }\end{array}$ & $\begin{array}{l}\text { Utres of } \\
\text { Oleset } \\
\text { Consumed }\end{array}$ & $\begin{array}{l}\text { Iltres } \\
\text { saved }\end{array}$ \\
\hline \multirow{5}{*}{$\begin{array}{l}\text { Average } \\
\text { Standard Deviation } \\
\text { Madimum } \\
\text { Minlmum } \\
\text { Total }\end{array}$} & 770.9 & 1188.1 & $65 \%$ & 227.9 & & & 7.2 & 67.2 & 570.9 & 1.6 & 638.5 & 0.5 & 202.1 & 25.9 \\
\hline & 141.5 & 116.8 & $10 \%$ & 32.0 & & & 4.8 & 73.7 & 141.5 & 0.8 & 208.2 & 0.2 & 43.5 & 28.4 \\
\hline & 1232.5 & 1250.0 & $99 \%$ & 322.1 & & & 27.7 & 203.0 & 1032.5 & 2.0 & 1232.5 & 1.0 & 322.1 & 79.3 \\
\hline & 6753132 & & & 1996559 & 100 & 15491 & & 588626 & 5001132 & & 5593287 & & 1770027 & 226532 \\
\hline & & & & & & & & $\begin{array}{r}1159845 \\
1177202 \\
17408\end{array}$ & \multicolumn{3}{|c|}{$\begin{array}{l}\text { Whd Energy Used } \\
\text { Whd Energy Avallable } \\
\text { Whd Energy Curaled }\end{array}$} & & & \\
\hline
\end{tabular}

Maxdmum number of whd turbines: 3

\begin{tabular}{|c|c|c|c|c|c|c|c|c|c|c|c|c|c|c|}
\hline $\begin{array}{l}\text { Time } \\
\text { (hr) }\end{array}$ & $\begin{array}{l}\text { Demand } \\
\text { (KW) }\end{array}$ & $\begin{array}{l}\text { Dlesel } \\
\text { Rating } \\
\text { (KWy) }\end{array}$ & $\begin{array}{l}\text { Percert of } \\
\text { Rating } \\
\text { Used }\end{array}$ & $\begin{array}{l}\text { Utres of } \\
\text { Dlesel } \\
\text { Consumed }\end{array}$ & $\begin{array}{l}\text { starts } \\
\text { coumer }\end{array}$ & $\begin{array}{l}\text { Dlesel } \\
\text { nn time } \\
\text { (hours) }\end{array}$ & $\begin{array}{l}\text { Whd } \\
\text { Speed } \\
(\mathrm{m} / \mathrm{s})\end{array}$ & $\begin{array}{l}\text { Single } \\
\text { Turtbere } \\
\text { Whind } \\
\text { Power } \\
\text { (KW) }\end{array}$ & $\begin{array}{l}\text { Maxdmum } \\
\text { Allowed } \\
\text { Wind } \\
\text { Demand } \\
\text { (KW) }\end{array}$ & $\begin{array}{l}\text { Number } \\
\text { of } \\
\text { Turbines }\end{array}$ & $\begin{array}{l}\text { Net } \\
\text { Demand } \\
\text { (kW) }\end{array}$ & $\begin{array}{l}\text { Percent of } \\
\text { Rating } \\
\text { Used }\end{array}$ & $\begin{array}{l}\text { Utres of } \\
\text { Diesel } \\
\text { Consumed }\end{array}$ & $\begin{array}{l}\text { Ittres } \\
\text { saved }\end{array}$ \\
\hline \multirow{5}{*}{$\begin{array}{l}\text { Average } \\
\text { Standard Deviation } \\
\text { Madmum } \\
\text { Minimum } \\
\text { Total }\end{array}$} & 770.9 & 1188.1 & $65 \%$ & 227.9 & & & 7.2 & 672 & 570.9 & 2.2 & 595.4 & 0.5 & 193.6 & 34.3 \\
\hline & 141.5 & 116.8 & $10 \%$ & 32.0 & & & 4.8 & 73.7 & 141.5 & 12 & 231.9 & 0.2 & 47.6 & 36.5 \\
\hline & 1232.5 & 1250.0 & $99 \%$ & 322.1 & & & 27.7 & 203.0 & 1032.5 & 3.0 & 1232.5 & 1.0 & 322.1 & 118.9 \\
\hline & 6753132 & & & 1996559 & 100 & 15491 & & 588626 & 5001132 & & 5215503 & & 1696241 & 300318 \\
\hline & & & & & & & & $\begin{array}{r}1537629 \\
1765878 \\
228250\end{array}$ & \multicolumn{5}{|c|}{$\begin{array}{l}\text { Whd Energy Used } \\
\text { Wind Energy Avallable } \\
\text { Whd Energy Curtalled }\end{array}$} & \\
\hline
\end{tabular}

Maxdmum number of Whd turbines: 4

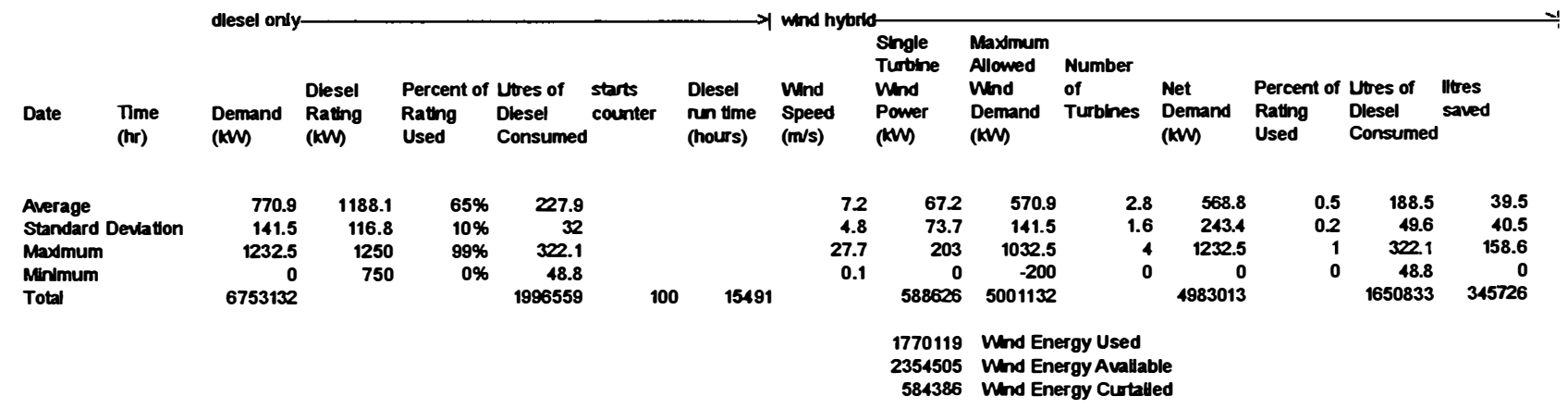




\section{ECONOMIC ANALYSIS}

Input Values

System load, (kWh/y)

Diesel energy $(k W h / y)$

Wind energy $(k W h / y)$

Diesel fuel usage, no wind (I/yr) F

Diesel fuel usage, with wind (I/yr) FL

Diesel fuel cost, $(\$ /)$

System life, (yrs)

General inflation

Fuel inflation

Discount rate

Interest

Term of loan, (yrs)

SL
Site: San Nicolas Island, CA Turbine: 225 kW, Commercial Quantity:

$6,753,132$
$6,165,512$
587,620
$1,996,559$
$1,881,789$
0.3012
20
$3.0 \%$
$4.0 \%$
$6.9 \%$
$10.0 \%$
10

\section{Calculated Values for Both Systems}

\section{Capital cost}

Initial payment on system

Loan

Annual payment

NPV of annual payment

Fuel cost per annum

NPV of fuel costs

Overhaul cost per annum

NPV of overhaul costs

O\&M costs per annum

NPV of O\&M costs

Total annual costs

Total system NPV, TNPV

Annual savings

Levelized cost of energy, COE

Payback period, years

Internal rate of return, IRR, $(x) \quad\left[(1+x)^{\wedge} L-1\right] /\left[x^{*}(1+x)^{\wedge} L\right]-P=$

\section{$\mathrm{C}=\mathrm{ICC}+\mathrm{BOS}$}

$A l=C-A d$

$A p=A l * C R F P$

Apnpv $=$ Ap ${ }^{*}$ PWFP

$A f=F L * F C$

Afnpv $=$ Af * PWFF

Ao

Aonpv $=A 0 *$ PWFO

Am

Amnpv $=A m^{*}$ PWFO $13,253,507$

$A t=A p+A f+A o+A m$

$=A d+$ sum(NPVs)

$S v=d s \mid A t-h b d A t$
$=\mathrm{TNPV}{ }^{*} \mathrm{CRFI} / \mathrm{SL}$
Diesel

Only

0

0

0

601,364

$9,124,287$

250,000

$3,462,757$

956,861

$1,253,507$
$1,808,225$

$25,840,551$

0.358

\section{Economic Factors}

Present worth factor of fuel costs, PWFF, $a=(1+e) /(1+d)$ Present worth factor of O\&M costs, PWFO, $a=(1+i) /(1+d)$ Present worth factor of interest payments, $P W F P, a=1 /(1+b)$

Capital recovery factor for system income, CRFI, $a=1 /(1+d)$

Capital recovery factor for interest payments, CRFP, $a=1 /(1+b)$

$\begin{array}{lrl}\text { a variable } & \text { n variable } & Y(a, n) \\ 0.97287184 & 20 & 15.17266 \\ 0.96351731 & 20 & 13.85103 \\ 0.9354537 & 10 & 7.05616 \\ \text { a variable } & \underline{\text { nvariable }} & \underline{X(a, n)}\end{array}$

0.9354537

200.09366054

$\begin{array}{lll}0.90909091 & 10 & 0.16274539\end{array}$

(NPV = net present value; ICC = initial capitol cost; BOS = balance of station $=26 \%$ ICC; O\&M = operations and maintenance $)$

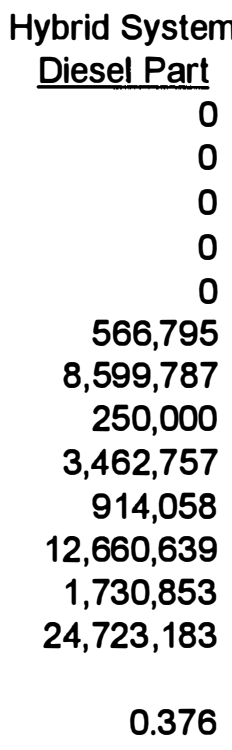

Hybrid System

0

0

0

6,795

250,000

462,757

$1,730,853$

0.376

0.000
Hybrid System

Hybrid System

Wind Part

337,500

337,500

Total

337,500

337,500

0

0

1,000

13,851

11,752

162,783

12,752

514,134

0.082

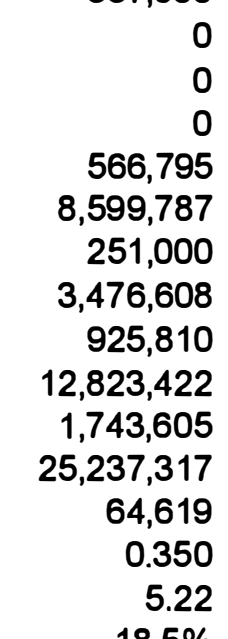

$18.5 \%$ 


\section{ECONOMIC ANALYSIS}

Input Values

System load, (kWh/y)

Diesel energy $(\mathrm{kWh} / \mathrm{y})$

Wind energy $(\mathrm{kWh} / \mathrm{y})$

Diesel fuel usage, no wind (I/yr) FL

Diesel fuel usage, with wind (I/yr) FL

Diesel fuel cost, $(\$ \lambda)$

System life, (yrs)

General inflation

Fuel inflation

Discount rate

Interest

Term of loan, (yrs)

\section{Calculated Values for Both Systems}

Capital cost

Initial payment on system

Loan

Annual payment

NPV of annual payment

Fuel cost per annum

NPV of fuel costs

Overhaul cost per annum

NPV of overhaul costs

O\&M costs per annum

NPV of O\&M costs

Total annual costs

Total system NPV, TNPV

Annual savings

Levelized cost of energy, COE

Payback period, years

Internal rate of return, IRR, (x)
Site:

Quantity:

San Nicolas Island, CA, $7.2 \mathrm{~m} / \mathrm{s}$ avg

225 kW, Commercial

\begin{tabular}{lr} 
SL & $6,753,132$ \\
& $5,593,287$ \\
FL & $1,159,845$ \\
FL & $1,996,559$ \\
FC & $1,770,027$ \\
L & 0.3012 \\
i & 20 \\
e & $3.0 \%$ \\
d & $4.0 \%$ \\
b & $6.9 \%$ \\
N & $10.0 \%$ \\
\hline
\end{tabular}

10

\section{Economic Factors}

Present worth factor of fuel costs, PWFF, $a=(1+e) /(1+d)$

Present worth factor of O\&M costs, PWFO, $a=(1+i) /(1+d)$

Present worth factor of interest payments, PWFP, $a=1 /(1+b)$

Capital recovery factor for system income, $C R F I, a=1 /(1+d)$

Capital recovery factor for interest payments, CRFP, $a=1 /(1+b)$ $\underline{\text { a variable }} \underline{\text { nvariable }} \underline{Y(a, n)}$

\begin{tabular}{|c|c|c|}
\hline 0.97287184 & 20 & 15.17266 \\
\hline 0.96351731 & 20 & 13.85103 \\
\hline 0.9354537 & 10 & 7.056 \\
\hline a variable & n variable & $X(a, n)$ \\
\hline
\end{tabular}

0.9354537

200.09366054

0.90909091

$10 \quad 0.16274539$

$(N P V=$ net present value $; I C C=$ initial capitol cost $; B O S=$ balance of station $=26 \% I C C ; O \& M=$ operations and maintenance $)$

\section{$C=I C C+B O S$}

Ad

$A l=C-A d$

$A p=A l *$ CRFP

Apnpv $=A p^{*}$ PWFP

$A f=F L{ }^{*} F C$

Afnpv $=A f$ * PWFF

Ao

Aonpv $=A o *$ PWFO

Am

$A m n p v=A m^{\star} P W F O$

$A t=A p+A f+A o+A m$

$=A d+$ sum(NPVs)

Sv = ds $A t-h b d$ At

$=$ TNPV ${ }^{\star} \mathrm{CRFI} / \mathrm{SL}$
Diesel

Only

0

0

0

0

601,364

$9,124,287$

250,000

$3,462,757$

956,861

$13,253,507$

$1,808,225$

$25,840,551$

0.358

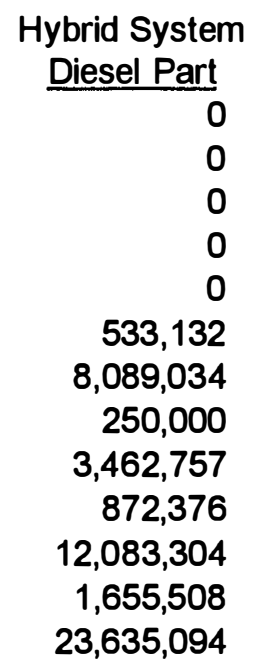

0.396
Hybrid System

Wind Part

675,000

675,000

0

0

0

2,000

27,702

23,197

321,301

25,197

$1,024,003$

0.083
Hybrid System

Total

675,000

675,000

0

533,132

$8,089,034$

252,000

$3,490,459$

895,573

$12,404,605$

$1,680,705$

$24,659,097$

127,519

0.342

5.29

$18.2 \%$ 


\section{ECONOMIC ANALYSIS}

\section{Input Values}

\section{System load, (kWh/y)}

Diesel energy $(k W h / y)$

Wind energy $(\mathrm{kWh} / \mathrm{y})$

Diesel fuel usage, no wind (I/yr) FL

Diesel fuel usage, with wind (I/yr) FL

Diesel fuel cost, $(\$ n)$

System life, (yrs)

General inflation

Fuel inflation

Discount rate

Interest

Term of loan, (yrs)

$S L$
Site: Turbine: Quantity:

San Nicolas Island, CA 225 kW, Commercial

$6,753,132$
$5,215,503$
$1,537,629$
$1,996,559$
$1,696,241$
0.3012
20
$3.0 \%$
$4.0 \%$
$6.9 \%$
$10.0 \%$
10

\section{Calculated Values for Both Systems}

Capital cost

Initial payment on system

Loan

Annual payment

NPV of annual payment

Fuel cost per annum

NPV of fuel costs

Overhaul cost per annum

NPV of overhaul costs

O\&M costs per annum

NPV of O\&M costs

Total annual costs

Total system NPV, TNPV

Annual savings

Levelized cost of energy, COE

Payback period, years

Internal rate of return, IRR, $(x) \quad\left[(1+x)^{\wedge} L-1\right] /\left[x^{*}(1+x)^{\wedge} L\right]-P=$
$C=I C C+B O S$

Diesel

Only

$\mathrm{Al}=\mathrm{C}-\mathrm{Ad}$

$A p=A l * C R F P$

Apnpv $=$ Ap ${ }^{\star} P W F P$

$A f=F L ~ * F C$

Afnpv $=$ Af * PWFF

Ao

Aonpv $=A o *$ PWFO

Am

$A m n p v=A m^{*} P W F O$

$A t=A p+A f+A o+A m$

$=A d+\operatorname{sum}(N P V s)$

$S v=d s l$ At - hbd At

$=\mathrm{TNPV}{ }^{*} \mathrm{CRFI} / \mathrm{SL}$

601,364

(3,253,50

\section{Economic Factors}

Present worth factor of fuel costs, PWFF, $a=(1+e) /(1+d)$ Present worth factor of O\&M costs, PWFO, $a=(1+i) /(1+d)$

Present worth factor of interest payments, $P W F P, a=1 /(1+b)$

Capital recovery factor for system income, CRFI, $a=1 /(1+d)$

Capital recovery factor for interest payments, CRFP, $a=1 /(1+b)$

$\begin{array}{lrl}\text { a variable } & \text { n variable } & Y(a, n) \\ 0.97287184 & 20 & 15.17266 \\ 0.96351731 & 20 & 13.85103 \\ 0.9354537 & 10 & 7.05616 \\ \text { a variable } & \underline{\text { nvariable }} & \underline{\text { X(a,n) }}\end{array}$

0.9354537

$20 \quad 0.09366054$

$\begin{array}{lll}0.90909091 & 10 & 0.16274539\end{array}$

$(N P V=$ net present value $; I C C=$ initial capitol cost $; B O S=$ balance of station $=26 \% I C C ; O \& M=$ operations and maintenance $)$

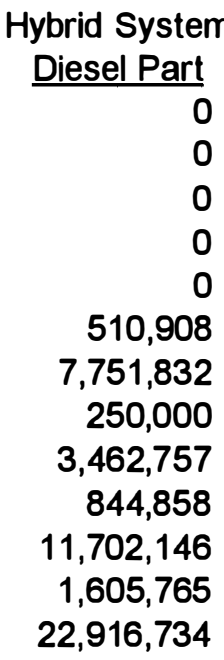

0.412

\begin{tabular}{|c|}
\hline \\
\hline$\frac{\text { Wind Part }}{1,012,500}$ \\
\hline 0 \\
\hline 0 \\
\hline 0 \\
\hline 0 \\
\hline 0 \\
\hline 3,000 \\
\hline 41,553 \\
\hline 30,753 \\
\hline 425,955 \\
\hline 33,753 \\
\hline $1,480,008$ \\
\hline
\end{tabular}

0.090
Hybrid System

Total

$1,012,500$

$1,012,500$

,124,287

250,000

, 462,757

$1,808,225$

0.358

0

510,908

$7,751,832$

253,000

$3,504,310$

875,610

$12,128,100$

$1,639,518$

$24,396,742$

168,707

0.338

6.00

$15.8 \%$ 
Input Values

System load, (kWh/y)

Diesel energy $(\mathrm{kWh} / \mathrm{y})$

Wind energy $(k W h / y)$

Quantity:

Diesel fuel usage, no wind (l/yr)

Diesel fuel usage, with wind (I/yr)

Diesel fuel cost, $(\$ n)$

System life, (yrs)

General inflation

Fuel inflation

Discount rate

Interest

Term of loan, (yrs)

$S L$

$\mathrm{FL}$

FC

L

i

e

d

b

N
4

$6,753,132$
$4,983,013$
$1,770,119$
$1,996,559$
$1,650,833$
0.3012
20
$3.0 \%$
$4.0 \%$
$6.9 \%$
$10.0 \%$
10

\section{Economic Factors}

Present worth factor of fuel costs, PWFF, $a=(1+e) /(1+d)$ Present worth factor of O\&M costs, PWFO, $a=(1+i) /(1+d)$

Present worth factor of interest payments, $P W F P, a=1 /(1+b)$

Capital recovery factor for system income, $\mathrm{CRFI}, \mathrm{a}=1 /(1+\mathrm{d})$

Capital recovery factor for interest payments, CRFP, $a=1 /(1+b)$

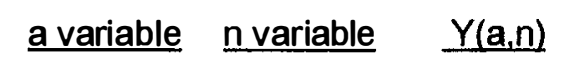

$\begin{array}{rrr}0.97287 & 20 & 15.17266 \\ 0.96352 & 20 & 13.85103 \\ 0.93545 & 10 & 7.05616 \\ \underline{\text { a variable }} & \underline{\text { n variable }} & \underline{X(a, n)} \\ 0.93545 & 20 & 0.09366 \\ 0.90909 & 10 & 0.16275\end{array}$

\section{Calculated Values for Both Systems}

Capital cost

Initial payment on system

Loan

Annual payment

NPV of annual payment

Fuel cost per annum

NPV of fuel costs

Overhaul cost per annum

NPV of overhaul costs

O\&M costs per annum

NPV of O\&M costs

Total annual costs

Total system NPV, TNPV

Annual savings

Levelized cost of energy, COE

Payback period, years

Internal rate of return, IRR, $(x)$

$$
C=I C C+B O S
$$$$
\text { Ad }
$$$$
A l=C-A d
$$$$
A p=A l * C R F P
$$

Apnpv $=A p^{\star} P W F P$

$\mathrm{Af}=\mathrm{FL}{ }^{*} \mathrm{FC}$

Afnpv $=A f *$ PWFF

Ao

Aonpv $=A o *$ PWFO

Am

Amnpv $=A m^{\star} P W F O$

$A t=A p+A f+A o+A m$

$=A d+$ sum(NPVs)

$S v=d s \mid A t-h b d A t$

$=$ TNPV ${ }^{*} \mathrm{CRFI} / \mathrm{SL}$

$P=C / S V$

$\left[(1+x)^{\wedge} L-1\right] /\left[x^{*}(1+x)^{\wedge} L\right]-P=$

\section{Diesel}

Only

0

0

0

0

0

601,364

$9,124,287$
250,000

$3,462,757$

956,861

$13,253,507$

$1,808,225$

$25,840,551$

0.358

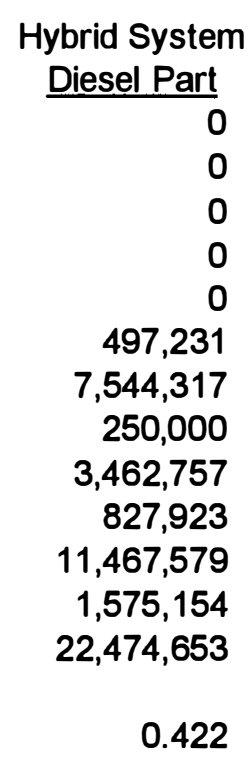

0.000

\begin{tabular}{rr}
$\begin{array}{c}\text { Hybrid System } \\
\text { Wind Part }\end{array}$ & $\begin{array}{r}\text { Hybrid System } \\
\text { Total }\end{array}$ \\
\hline $1,350,000$ & $1,350,000$ \\
$1,350,000$ & $1,350,000$ \\
0 & 0 \\
0 & 0 \\
0 & 0 \\
0 & 497,231 \\
0 & $7,544,317$ \\
4,000 & 254,000 \\
55,404 & $3,518,161$ \\
35,402 & 863,325 \\
490,359 & $11,957,939$ \\
39,402 & $1,614,556$ \\
$1,895,763$ & $24,370,416$ \\
& 193,669 \\
0.100 & 0.338 \\
& 6.97 \\
& $13.1 \%$
\end{tabular}

$(N P V=$ net present value $; I C C=$ initial capitol cost; $B O S=$ balance of station $=26 \% I C C ; O \& M=$ operations and maintenance $)$ 
Maximum number of wind turbines: 2; Average wind speed: $6.5 \mathrm{~m} / \mathrm{s}$ ( $10 \%$ low)

\begin{tabular}{|c|c|c|c|c|c|c|c|c|c|c|c|c|c|c|}
\hline $\begin{array}{c}\text { Time } \\
\text { (hr) }\end{array}$ & $\begin{array}{l}\text { Demand } \\
(\mathrm{KW})\end{array}$ & $\begin{array}{l}\text { Diesel } \\
\text { Rating } \\
(\mathbf{k W})\end{array}$ & $\begin{array}{c}\text { Percent of } \\
\text { Rating } \\
\text { Used }\end{array}$ & $\begin{array}{l}\text { Litres of } \\
\text { Diesel } \\
\text { Consumed }\end{array}$ & $\begin{array}{l}\text { starts } \\
\text { counter }\end{array}$ & $\begin{array}{l}\text { Diesel } \\
\text { run time } \\
\text { (hours) }\end{array}$ & $\begin{array}{l}\text { Wind } \\
\text { Speed } \\
(\mathrm{m} / \mathrm{s})\end{array}$ & $\begin{array}{c}\text { Single } \\
\text { Turbine } \\
\text { Wind } \\
\text { Power } \\
\text { (KW) }\end{array}$ & $\begin{array}{l}\text { Maximum } \\
\text { Allowed } \\
\text { Wind } \\
\text { Demand } \\
\text { (kW) }\end{array}$ & $\begin{array}{l}\text { Number } \\
\text { of } \\
\text { Turbines }\end{array}$ & $\begin{array}{c}\text { Net } \\
\text { Demand } \\
(k W)\end{array}$ & $\begin{array}{l}\text { Percent of } \\
\text { Rating } \\
\text { Used }\end{array}$ & $\begin{array}{l}\text { Litres of } \\
\text { Diesel } \\
\text { Consumed }\end{array}$ & $\begin{array}{l}\text { litres } \\
\text { saved }\end{array}$ \\
\hline \multirow{3}{*}{$\begin{array}{l}\text { Standard Deviation } \\
\text { Maximum }\end{array}$} & 770.9 & 1188.1 & $65 \%$ & 227.9 & & & 6.5 & 57.7 & 570.9 & 1.5 & 657.2 & 0.6 & 205.7 & 22.2 \\
\hline & 141.5 & 116.8 & $10 \%$ & 32.0 & & & 4.3 & 69.3 & 141.5 & 0.9 & 201.5 & 0.2 & 42.3 & 26.7 \\
\hline & 1232.5 & 1250.0 & $99 \%$ & 322.1 & & & 24.9 & 203.0 & 1032.5 & 2.0 & 1232.5 & 1.0 & 322.1 & 79.3 \\
\hline \multirow{3}{*}{$\begin{array}{l}\text { Minimum } \\
\text { Total }\end{array}$} & 0.0 & 750.0 & $0 \%$ & 48.8 & & & 0.1 & 0.0 & -200.0 & 0.0 & 0.0 & 0.0 & 48.8 & 0.0 \\
\hline & 6753132 & & & 1996559 & 100 & 15491 & & 505328 & 5001132 & & 5756721 & & 1801947 & 194612 \\
\hline & & & & & & & & $\begin{array}{r}996411 \\
1010656 \\
14245\end{array}$ & \multicolumn{5}{|c|}{$\begin{array}{l}\text { Wind Energy Used } \\
\text { Wind Energy Available } \\
\text { Wind Energy Curtailed }\end{array}$} & \\
\hline
\end{tabular}

Maximum number of wind turbines: 2; Average wind speed: $7.2 \mathrm{~m} / \mathrm{s}$ (baseline)

\begin{tabular}{|c|c|c|c|c|c|c|c|c|c|c|c|c|c|c|}
\hline $\begin{array}{c}\text { Time } \\
\text { (hr) }\end{array}$ & $\begin{array}{l}\text { Demand } \\
(\mathrm{KW})\end{array}$ & $\begin{array}{l}\text { Diesel } \\
\text { Rating } \\
(\mathbf{k W})\end{array}$ & $\begin{array}{c}\text { Percent of } \\
\text { Rating } \\
\text { Used }\end{array}$ & $\begin{array}{l}\text { Litres of } \\
\text { Diesel } \\
\text { Consumed }\end{array}$ & $\begin{array}{c}\text { starts } \\
\text { counter }\end{array}$ & $\begin{array}{l}\text { Diesel } \\
\text { run time } \\
\text { (hours) }\end{array}$ & $\begin{array}{l}\text { Wind } \\
\text { Speed } \\
(\mathrm{m} / \mathrm{s})\end{array}$ & $\begin{array}{c}\text { Single } \\
\text { Turbine } \\
\text { Wind } \\
\text { Power } \\
\text { (KW) }\end{array}$ & $\begin{array}{l}\text { Maximum } \\
\text { Allowed } \\
\text { Wind } \\
\text { Demand } \\
(\mathbf{K W})\end{array}$ & $\begin{array}{c}\text { Number } \\
\text { of } \\
\text { Turbines }\end{array}$ & $\begin{array}{l}\text { Net } \\
\text { Demand } \\
(K W)\end{array}$ & $\begin{array}{l}\text { Percent of } \\
\text { Rating } \\
\text { Used }\end{array}$ & $\begin{array}{l}\text { Litres of } \\
\text { Diesel } \\
\text { Consumed }\end{array}$ & $\begin{array}{l}\text { litres } \\
\text { saved }\end{array}$ \\
\hline \multirow{5}{*}{$\begin{array}{l}\text { Average } \\
\text { Standard Deviation } \\
\text { Maximum } \\
\text { Minimum } \\
\text { Total }\end{array}$} & 770.9 & 1188.1 & $65 \%$ & 227.9 & & & 7.2 & 67.2 & 570.9 & 1.6 & 638.5 & 0.5 & 202.1 & 25.9 \\
\hline & 141.5 & 116.8 & $10 \%$ & 32.0 & & & 4.8 & 73.7 & 141.5 & 0.8 & 208.2 & 0.2 & 43.5 & 28.4 \\
\hline & 1232.5 & 1250.0 & $99 \%$ & 322.1 & & & 27.7 & 203.0 & 1032.5 & 2.0 & 1232.5 & 1.0 & 322.1 & 79.3 \\
\hline & 0.0 & 750.0 & $0 \%$ & 48.8 & & & 0.1 & 0.0 & -200.0 & 0.0 & 0.0 & 0.0 & 48.8 & 0.0 \\
\hline & 6753132 & & & 1996559 & 100 & 15491 & & 588626 & 5001132 & & 5593287 & & 1770027 & 226532 \\
\hline & & & & & & & & $\begin{array}{r}1159845 \\
1177252 \\
17408\end{array}$ & $\begin{array}{l}\text { Wind Ener } \\
\text { Wind Ener } \\
\text { Wind Ener }\end{array}$ & $\begin{array}{l}\text { rgy Used } \\
\text { rgy Available } \\
\text { rgy Curtailec }\end{array}$ & & & & \\
\hline
\end{tabular}

Maximum number of wind turbines: 2; Average wind speed: $7.9 \mathrm{~m} / \mathrm{s}$ (10 \% high)

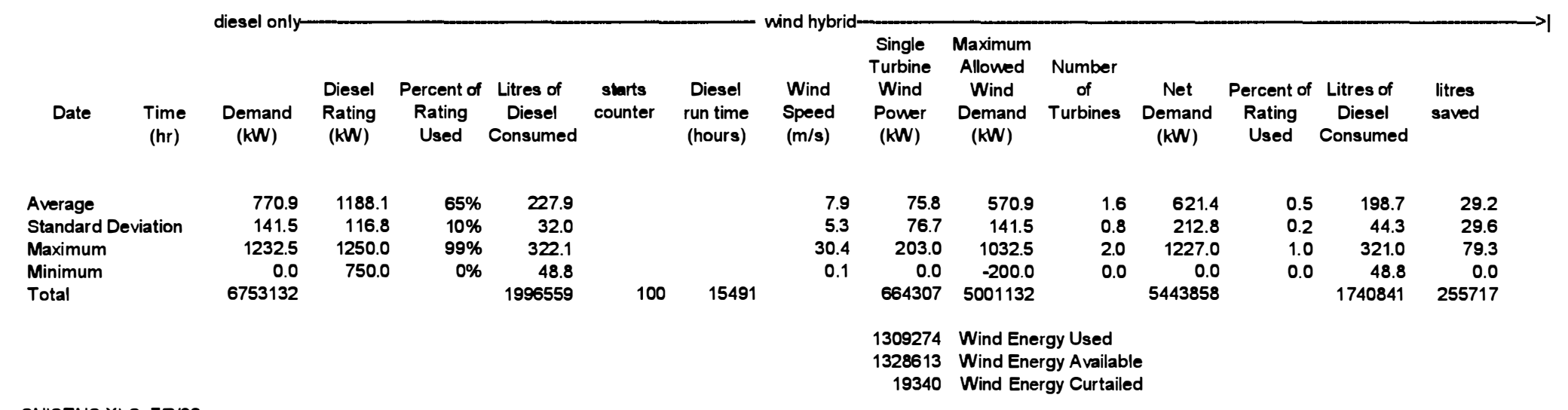




\section{ECONOMIC ANALYSIS}

\section{Input Values}

System load, (kWh/y)

Diesel energy $(k W h / y)$

Wind energy $(\mathrm{kWh} / \mathrm{y})$

Diesel fuel usage, no wind (I/yr) FL Diesel fuel usage, with wind (I/yr) FL

Diesel fuel cost, $(\$ \Lambda)$

System life, (yrs)

General inflation

Fuel inflation

Discount rate

Interest

Term of loan, (yrs)

\section{Calculated Values for Both Systems}

\section{Capital cost}

Initial payment on system

Loan

Annual payment

NPV of annual payment

Fuel cost per annum

NPV of fuel costs

Overhaul cost per annum

NPV of overhaul costs

O\&M costs per annum

NPV of O\&M costs

Total annual costs

Total system NPV, TNPV

Annual savings

Levelized cost of energy, COE

Payback period, years

Intemal rate of retum, IRR, $(x)$
Site:

Turbine:

Quantity:

San Nicolas Island, CA, $6.5 \mathrm{~m} / \mathrm{s}$ avg

225 kW, Commercial

\section{2}

\begin{tabular}{lr} 
SL & $6,753,132$ \\
& $5,756,721$ \\
FL & 996,411 \\
FL & $1,996,559$ \\
FC & $1,801,947$ \\
L & 0.3012 \\
i & 20 \\
e & $3.0 \%$ \\
d & $4.0 \%$ \\
b & $6.9 \%$ \\
N & $10.0 \%$ \\
\hline
\end{tabular}

10

\section{Economic Factors}

Present worth factor of fuel costs, PWFF, $a=(1+e) /(1+d)$ Present worth factor of O\&M costs, PWFO, $a=(1+i) /(1+d)$ Present worth factor of interest payments, PWFP, $a=1 /(1+b)$

Capital recovery factor for system income, $C R F I, a=1 /(1+d)$

Capital recovery factor for interest payments, CRFP, $a=1 /(1+b)$

\begin{tabular}{|c|c|c|}
\hline a variable & n variable & $Y(a, n)$ \\
\hline 0.97287184 & 20 & 15.17266 \\
\hline 0.96351731 & 20 & 13.85103 \\
\hline 0.9354537 & 10 & 7.05616 \\
\hline a variable & $\mathrm{n}$ variable & $X(a, n)$ \\
\hline
\end{tabular}

0.9354537

$20 \quad 0.09366054$

0.90909091

$10 \quad 0.16274539$

$(N P V=$ net present value $; I C C=$ initial capitol cost; $B O S=$ balance of station $=26 \% I C C ; O \& M=$ operations and maintenance $)$

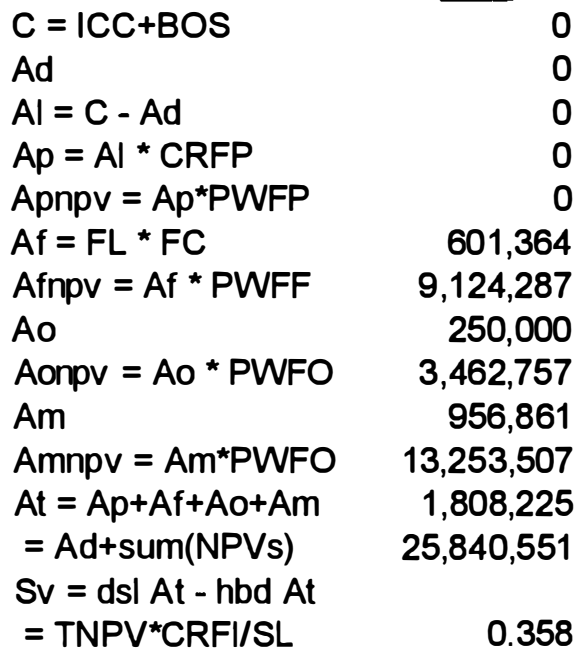

$\left[(1+x)^{\wedge} L-1\right] /\left[x^{*}(1+x)^{\wedge} L\right]-P=$

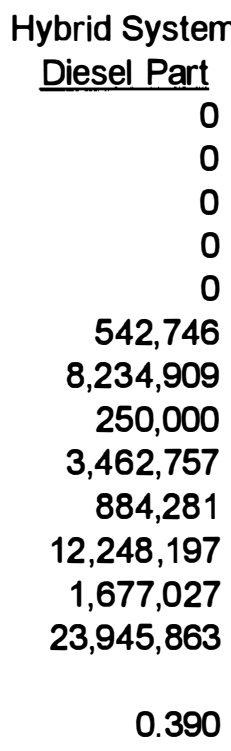

0.000
Hybrid System

Total

675,000

675,000

675,000

0

0

542,746

$8,234,909$

252,000

$3,490,459$

904,209

$12,524,224$

$1,698,955$

$24,924,591$

109,269

0.346

6.18

$15.2 \%$ 


\section{ECONOMIC ANALYSIS}

Input Values

System load, (kWh/y)

Diesel energy $(k W h / y)$

Wind energy (kWh/y)

Diesel fuel usage, no wind (I/yr) FL

Diesel fuel usage, with wind (1/yr) FL

Diesel fuel cost, $(\$ \Omega)$

System life, (yrs)

General inflation

Fuel inflation

Discount rate

Interest

Term of loan, (yrs)

$S L$
Site:

Turbine:

Quantity:

Nicolas Island, CA, $7.2 \mathrm{~m} / \mathrm{s}$ avg

\section{5 kW, Commercial}

$6,753,132$

$5,593,287$

$1,159,845$

$1,996,559$

$1,770,027$

FC $\quad 0.3012$

$\begin{array}{lr}\mathrm{L} & 20 \\ \mathrm{i} & 3.0 \%\end{array}$

$4.0 \%$

$6.9 \%$

$10.0 \%$

10

\section{Economic Factors}

Present worth factor of fuel costs, PWFF, $a=(1+e) /(1+d)$ Present worth factor of O\&M costs, PWFO, $a=(1+i) /(1+d)$ Present worth factor of interest payments, PWFP, $a=1 /(1+b)$

Capital recovery factor for system income, CRFI, $a=1 /(1+d)$

Capital recovery factor for interest payments, CRFP, $a=1 /(1+b)$

$\begin{array}{lrl}\text { a variable } & \text { n variable } & Y(a, n) \\ 0.97287184 & 20 & 15.17266 \\ 0.96351731 & 20 & 13.85103 \\ 0.9354537 & 10 & 7.05616 \\ \text { a variable } & \underline{\text { nvariable }} & \underline{X(a, n)}\end{array}$

0.9354537

200.09366054

0.90909091

$10 \quad 0.16274539$

\section{Calculated Values for Both Systems}

\section{Capital cost}

Initial payment on system

Loan

Annual payment

NPV of annual payment

Fuel cost per annum

NPV of fuel costs

Overhaul cost per annum

NPV of overhaul costs

O\&M costs per annum

NPV of O\&M costs

Total annual costs

Total system NPV, TNPV

Annual savings

Levelized cost of energy, COE

Payback period, years

Internal rafe of return, IRR, $(x) \quad\left[(1+x)^{\wedge} L-1\right] /\left[x^{\star}(1+x)^{\wedge} L\right]-P=$

\section{$C=I C C+B O S$}

Ad

$A l=C-A d$

$A p=A l * C R F P$

Apnpv $=A p^{*} P W F P$

$\mathrm{Af}=\mathrm{FL}{ }^{*} \mathrm{FC}$

Afnpv $=A f *$ PWFF

Ao

Aonpv $=A o *$ PWFO

Am

Amnpv $=A m^{*} P W F O$

$A t=A p+A f+A o+A m$

$=A d+\operatorname{sum}(N P V s)$

$S v=d s \mid A t-h b d A t$

$=$ TNPV ${ }^{*}$ CRFI/SL

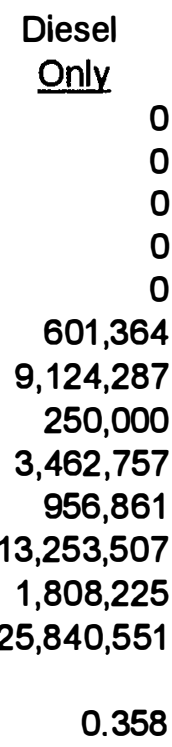

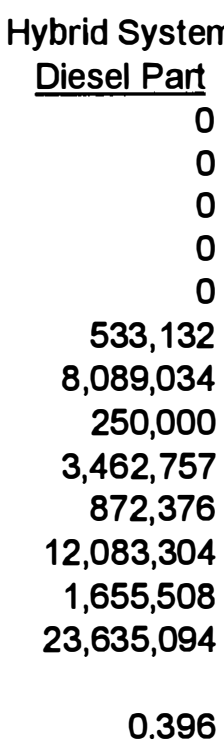

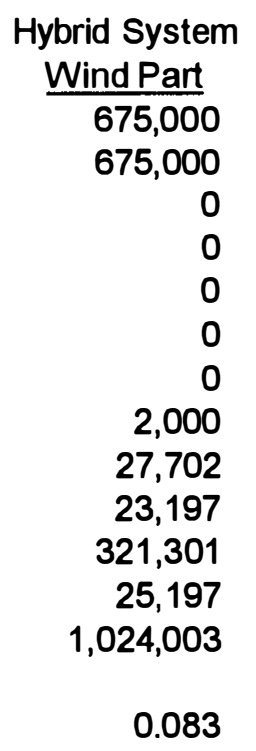

0.000
Hybrid System

Total

675,000

675,000

0

0

533,132

$8,089,034$

252,000

$3,490,459$

895,573

$12,404,605$

$1,680,705$

$24,659,097$

127,519

0.342

5.29

$18.2 \%$

$(N P V=$ net present value $; I C C=$ initial capitol cost; $B O S=$ balance of station $=26 \% I C C ; O \& M=$ operations and maintenance $)$ 


\section{Quantity:}

Input Values

System load, (kWh/y)

Diesel energy $(k W h / y)$

SL

Wind energy $(\mathrm{kWh} / \mathrm{y})$

$6,753,132$

$5,443,858$

$1,309,274$

Diesel fuel usage, no wind (I/yr) FL

Diesel fuel usage, with wind (I/yr) FL

Diesel fuel cost, $(\$ \Lambda)$

System life, (yrs)

General inflation

Fuel inflation

Discount rate

Interest

Term of loan, (yrs)

\section{Calculated Values for Both Systems}

Capital cost

Initial payment on system

Loan

Annual payment

NPV of annual payment

Fuel cost per annum

NPV of fuel costs

Overhaul cost per annum

NPV of overhaul costs

O\&M costs per annum

NPV of O\&M costs

Total annual costs

Total system NPV, TNPV

Annual savings

Levelized cost of energy, COE

Payback period, years

Internal rate of return, IRR, (x)

\section{$\mathrm{C}=1 \mathrm{CC}+\mathrm{BOS}$}

Ad

$A l=C-A d$

$A p=A l * C R F P$

Apnpv $=A p^{\star} P W F P$

$\mathrm{Af}=\mathrm{FL}{ }^{\star} \mathrm{FC}$

Afnpv $=A f *$ PWFF

Ao

Am

$A m n p v=A m^{\star} P W F O$

$A t=A p+A f+A o+A m$

$=A d+$ sum(NPVs)

Sv $=$ ds $\mid$ At - hbd At

$=\mathrm{TNPV}^{*} \mathrm{CRFI} / \mathrm{SL}$
Aonpv $=A o$ * $\mathrm{PWFO}$
0.3012

20

$3.0 \%$

$4.0 \%$

$6.9 \%$

$10.0 \%$

10

\section{Economic Factors}

Present worth factor of fuel costs, PWFF, $a=(1+e) /(1+d)$ Present worth factor of O\&M costs, PWFO, $a=(1+i) /(1+d)$ Present worth factor of interest payments, PWFP, $a=1 /(1+b)$

Capital recovery factor for system income, CRFI, $a=1 /(1+d)$ Capital recovery factor for interest payments, CRFP, $a=1 /(1+b)$

\begin{tabular}{|c|c|c|}
\hline a variable & $\underline{\text { n variable }}$ & $Y(a, n)$ \\
\hline 0.97287184 & 20 & 15.17266 \\
\hline 0.96351731 & 20 & 13.85103 \\
\hline 0.9354537 & 10 & 7.05616 \\
\hline a variable & $\underline{n}$ variable & $\underline{X(a, n)}$ \\
\hline
\end{tabular}

0.9354537

$20 \quad 0.09366054$

0.90909091

$10 \quad 0.16274539$

\begin{tabular}{|c|c|c|c|}
\hline $\begin{array}{l}\text { Diesel } \\
\text { Only }\end{array}$ & $\begin{array}{c}\text { Hybrid System } \\
\text { Diesel Part }\end{array}$ & $\begin{array}{l}\text { Hybrid System } \\
\text { Wind Part }\end{array}$ & $\begin{array}{c}\text { Hybrid System } \\
\text { Total }\end{array}$ \\
\hline 0 & 0 & 675,000 & $\overline{675,000}$ \\
\hline 0 & 0 & 675,000 & 675,000 \\
\hline 0 & 0 & 0 & 0 \\
\hline 0 & 0 & 0 & 0 \\
\hline 0 & 0 & 0 & 0 \\
\hline 601,364 & 524,341 & 0 & 524,341 \\
\hline $9,124,287$ & $7,955,654$ & 0 & $7,955,654$ \\
\hline 250,000 & 250,000 & 2,000 & 252,000 \\
\hline $3,462,757$ & $3,462,757$ & 27,702 & $3,490,459$ \\
\hline 956,861 & 861,491 & 26,185 & 887,677 \\
\hline $13,253,507$ & $11,932,540$ & 362,696 & $12,295,236$ \\
\hline $1,808,225$ & $1,635,833$ & 28,185 & $1,664,018$ \\
\hline $25,840,551$ & $23,350,951$ & $1,065,398$ & $\begin{array}{r}24,416,349 \\
144,206\end{array}$ \\
\hline 0.358 & 0.402 & 0.076 & $\begin{array}{r}0.339 \\
4.68\end{array}$ \\
\hline$=$ & & & $20.9 \%$ \\
\hline
\end{tabular}

$(N P V=$ net present value $; I C C=$ initial capitol cost; $B O S=$ balance of station $=26 \% I C C ; O \& M=$ operations and maintenance $)$ 


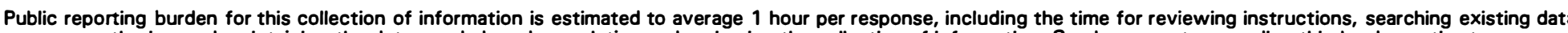

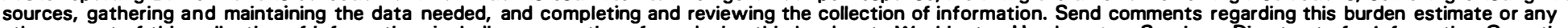

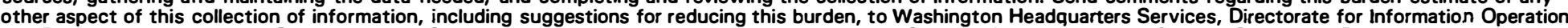

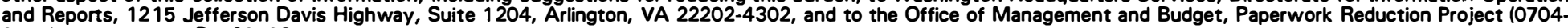
0188), Washington, DC 20503.

\begin{tabular}{|l|l|l|}
\hline 1. & $\begin{array}{c}\text { 2. REPORT DATE } \\
\text { July } 1996\end{array}$ & $\begin{array}{l}\text { 3. REPORT TYPE AND DATES COVERED } \\
\text { Subcontract Report }\end{array}$ \\
\hline
\end{tabular}

4. TITLE AND SUBTITLE

Hybrid Energy System Cost Analysis: San Nicolas Island, California

6. AUTHOR(S)

Ed McKenna, NREL

Timothy L. Olsen

Timothy L. Olsen Consulting

1428 S. Humboldt Street

Denver, CO 80210

7. PERFORMING ORGANIZATION NAME(S) AND ADDRESS(ES)

Timothy L. Olsen Consulting

5. FUNDING NUMBERS

C: CAK-6-15387-01

TA: WF234401

1428 S. Humboldt Street

Denver, CO 80210

9. SPONSORING/MONITORING AGENCY NAME(S) AND ADDRESS(ES)

National Renewable Energy Laboratory

1617 Cole Blvd.

Golden, CO 80401-3393
8. PERFORMING ORGANIZATION REPORT NUMBER

11. SUPPLEMENTARY NOTES

NREL Technical Monitor: Ed McKenna

12a. DISTRIBUTION/AVAILABILITY STATEMENT

National Technical Information Service

U.S. Department of Commerce

5285 Port Royal Road

Springfield, VA 22161 12b. DISTRIBUTION CODE

UC-1213

13. ABSTRACT (Maximum 200 words)

San Nicolas Island has an excellent wind resource, with an annual average wind speed of $7.2 \mathrm{~m} / \mathrm{s}(14.0) \mathrm{knots})$ as measured by the National Renewable Energy Laboratory (NREL) at $30.5 \mathrm{~m} \mathrm{(100} \mathrm{ft)} \mathrm{at} \mathrm{Facility} \mathrm{No.} 186$ in the August 1994 - July 1995 data collection period. Recognizing this, a hybrid energy system was modeled to examine the merits of supplementing the existing diesel generators with a modest portion of wind energy generation. Using conservative assumptions (unfavorable to wind energy) at every step in the spreadsheet model, the hybrid system displayed favorable operation and economics. The levelized cost of energy (COE) for the hybrid case using four $225 \mathrm{~kW}$ wind turbines is $\$ 0.338 / \mathrm{kWh}$ vs. $\$ 0.358 / \mathrm{kWh}$ for the baseline case. This would create a COE savings of $5.6 \%$. The payback period is 6.97 years, the internal rate of return $13.1 \%$. The two-turbine case had a COE of $\$ 0.342 / \mathrm{kWh}$, saving $4.5 \%$, with a payback period of 5.29 years, and an internal rate of return of $18.2 \%$. The COE for this case is relatively insensitive to annual average wind speed, varying $1 \%$ for a $10 \%$ change in wind speed. But the payback period is quite sensitive to wind speed, varying $11 \%$ to $17 \%$ for a $10 \%$ change in wind speed.

14. SUBJECT TERMS

wind energy; hybrid energy systems
15. NUMBER OF PAGES

16. PRICE CODE

20. LIMITATION OF ABSTRACT

UL

\section{OF REPORT}

Unclassified

7. SECURITY CLASSIFICATION
19. SECURITY CLASSIFICATION OF ABSTRACT

Unclassified
Standard Form 298 (Rev. 2-89) Prescribed by ANSI Std. 239-18 